\title{
In situ localization and tissue distribution of ostreid herpesvirus 1 proteins in infected Pacific oyster, Crassostrea gigas
}

\author{
Martenot Claire ${ }^{1,{ }^{*}}$, Segarra Amelie ${ }^{1}$, Baillon Laury ${ }^{1}$, Faury Nicole ${ }^{1}$, Houssin Maryline ${ }^{3}$, Renault \\ Tristan $^{2}$
}

${ }^{1}$ IFREMER, RBE-SG2M-LGPMM, Station La Tremblade, Avenue de Mus de loup, 17390-La

Tremblade, France

${ }^{2}$ IFREMER, PDG-RBE, Centre de Nantes, Rue de l'Ile d'Yeu, F-44311 Nantes, France

${ }^{3}$ LABEO Frank Duncombe, F-14053 Caen, France

* Corresponding author : Claire Martenot, email address : claire.martenot@ifremer.fr

\begin{abstract}
:
Immunohistochemistry (IHC) assays were conducted on paraffin sections from experimentally infected spat and unchallenged spat produced in hatchery to determine the tissue distribution of three viral proteins within the Pacific oyster, Crassostrea gigas. Polyclonal antibodies were produced from recombinant proteins corresponding to two putative membrane proteins and one putative apoptosis inhibitor encoded by ORF 25,72 , and 87 , respectively. Results were then compared to those obtained by in situ hybridization performed on the same individuals, and showed a substantial agreement according to Landis and Koch numeric scale. Positive signals were mainly observed in connective tissue of gills, mantle, adductor muscle, heart, digestive gland, labial palps, and gonads of infected spat. Positive signals were also reported in digestive epithelia. However, few positive signals were also observed in healthy appearing oysters (unchallenged spat) and could be due to virus persistence after a primary infection.
\end{abstract}

Cellular localization of staining seemed to be linked to the function of the viral protein targeted. A nucleus staining was preferentially observed with antibodies targeting the putative apoptosis inhibitor protein whereas a cytoplasmic localization was obtained using antibodies recognizing putative membrane proteins. The detection of viral proteins was often associated with histopathological changes previously reported during OsHV-1 infection by histology and transmission electron microscopy. Within the $6 \mathrm{~h}$ after viral suspension injection, positive signals were almost at the maximal level with the three antibodies and all studied organs appeared infected at $28 \mathrm{~h}$ post viral injection. Connective tissue appeared to be a privileged site for OsHV-1 replication even if positive signals were observed in the epithelium cells of different organs which may be interpreted as a hypothetical portal of entry or release for the virus. IHC constitutes a suited method for analyzing the early infection stages of OsHV-1 infection and a useful tool to investigate interactions between OsHV-1 and its host at a protein level. 


\section{Graphical abstract}

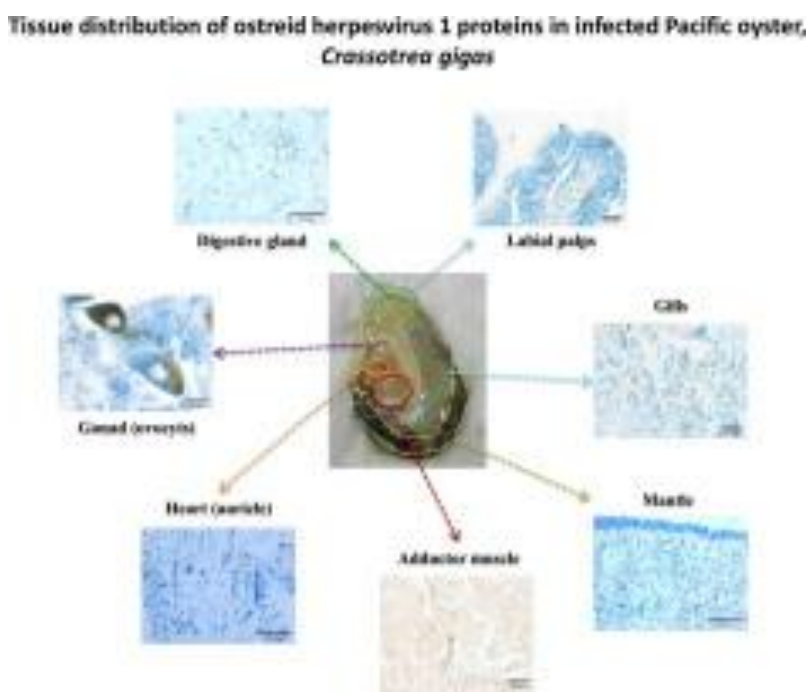

\section{Highlights}

- Tissue distribution of three viral proteins was investigated on paraffin sections from experimentally infected Pacific oyster. Positive signals were mainly observed in connective tissue in most of organs. - A substantial agreement was obtained between in situ hybridization and immunohistochemistry results.

Keywords : HV-1, Viral proteins, Crassostrea gigas 


\section{Introduction}

For several decades, mass mortality outbreaks of the Pacific oyster, Crassostrea gigas, have been regularly reported throughout the world and consequently dramatic losses in production were recorded, generating a decline in the oyster farming industry. Spat mortality events are most often associated with the detection of ostreid herpesvirus 1 (OsHV-1) which is the type species within the genus Ostreavirus and the Malacoherpesviridae family (Davison et al., 2009, 2005; Le Deuff and Renault, 1999). From 2008 onwards, OsHV-1 variants had been reported and a variant called $\mu$ Var was mainly detected along the French coast (Martenot et al., 2012, 2011; Renault et al., 2014, 2012; Segarra et al., 2010). The variant $\mu$ Var is characterized by 26 mutations in two regions of the viral genome: the $\mathrm{C}$ region (ORF 4/5), and an IAP region (ORF 42/43) as reported by Segarra et al. (2010) . OsHV-1 reference type and variants have been detected in France (Le Deuff and Renault, 1999; Nicolas et al., 1992; Renault and Lipart, 1998), Ireland (Clegg et al., 2014; Lynch et al., 2012; Peeler et al., 2012), Spain (Aranguren et al., 2012; Da Silva et al., 2008; Roque et al., 2012), Italy (Domeneghetti et al., 2014; Dundon et al., 2011), Portugal (Batista et al., 2014), South Korea (Hwang et al., 2013; Jee et al., 2013), United States (Burge et al., 2011, 2006; Friedman et al., 2005), Mexico (Grijalva-Chon et al., 2013), Australia (Jenkins et al., 2013; Paul-Pont et al., 2014, 2013a, 2013b), and New Zealand (Bingham et al., 2013; Keeling et al., 2014; Renault et al., 2012; Whittington et al., 2015) during mortality outbreaks or without oyster mortality. Juveniles (less than 18 months old) were more impacted by mortality associated with OsHV-1 detection than older ones (oysters more than 18 months) (Francois et al., 2009; Renault, 2006) even if OsHV-1 DNA or proteins were found at different stages of development (Arzul et al., 2002; Martenot et al., 2012, 2011). OsHV-1 DNA was also detected in different oyster species (Comps and Cochennec, 1993; Hine et al., 1998; Hine and Thorne, 1997), clams (Renault et al., 2001a, 2001b), and scallops (Arzul et al., 2001), suggesting a broad host range, such as with pseudorabies virus (Aujeszky's disease) (Flamand et al., 1998). 
Several molecular diagnostic assays were developed to screen for OsHV-1 including real-time PCR based on TaqMan ${ }^{\circledR}$ and SYBR ${ }^{\circledR}$ Green chemistry (Burge et al., 2011; Martenot et al., 2010; Pepin et al., 2008; Webb et al., 2007), conventional PCR (Arzul et al., 2002; Barbosa-Solomieu et al., 2004; Batista et al., 2007; Renault et al., 2000), real-time reverse transcription PCR (Burge and Friedman, 2012; Martenot et al., 2015; Segarra et al., 2014), propidium monoazide (PMA) real-time PCR (Moreau et al., 2015), and in situ hybridization (ISH) (Arzul et al., 2002; Corbeil et al., 2015; Lipart and Renault, 2002). Histology associated to ISH or immunohistochemistry (IHC) assay allows studying the virus distribution in numerous organs of the same animal based on positive signals detection albeit this approach is longer than PCR. In addition, histological changes are subtle and difficult to detect in OsHV-1 infections and consequently ISH and IHC are powerful approaches to better understand this disease. Transcriptomic approaches (Jouaux et al., 2013; Rosani et al., 2014; Segarra et al., 2014) were conducted to better understand the viral cycle, especially the gene expression sequence (Segarra et al., 2014) but there are no data related to the viral protein expression and distribution during an experimental infection in seed and juvenile oysters. Previously, Arzul et al. (2002) detected OsHV-1 proteins in cells localized in connective tissue of gills, mantle, adductor muscle, and the gonad in asymptomatic $C$. gigas adults using antibodies produced against the entire virus. Only $30 \%$ of OsHV-1 proteins have putative function obtained using protein prediction software and $70 \%$ of the OsHV-1 genome correspond to proteins of unknown function presenting no homology with protein sequences found in biological data banks (i.e. Genbank).

This study details the first time that an IHC assay has been used to localize and describe the distribution of three viral proteins in OsHV-1 infected spat during an experimental infection and in unchallenged spat produced in hatchery. In this context, three polyclonal antibodies were produced by ProteoGenix (Schiltigheim, France) from three recombinant proteins and targeted two putative structural proteins (class I membrane proteins) and one putative apoptosis inhibitor containing a 
"baculovirus inhibition of apoptosis protein repeat" (BIR) domain, encoded by ORF 25, 72, and 87, respectively. IHC results were then compared with those obtained by in situ hybridization (ISH) performed on the same oysters targeting ORF4/5 region encoding two proteins of unknown function (Corbeil et al., 2015; Lipart and Renault, 2002). The comparison between methods of virus detection at the DNA, RNA, and protein level, and the analysis of immunohistochemistry results by a biometric method called Landis and Koch numeric scale constitutes an innovative approach. In addition, the present study constitutes the first report of the viral protein detection at different times post OsHV-1 infection in controlled conditions with three different polyclonal antibodies within same individuals.

\section{Materials and Methods}

\section{Biological material}

The biological material selected for the present study, was previously used to describe the tissue distribution of OsHV-1 RNA and DNA during a viral challenge by in situ hybridization (Segarra et al., 2016) in order to realize a complementary and global approach on the same oysters at different expression level. The spat used were hatchery-produced, nine months old and measured around three centimeters (Segarra et al., 2016). The DNA and the RNA probes targeted the C region (ORF 4 encoding a protein of unknown function) and the ORF 87 (encoding a putative apoptosis inhibitor), respectively (Segarra et al., 2016). These data were compared with those obtained in the present work by IHC to investigate the specificity of antibodies.

A viral suspension prepared from experimentally infected oysters, was injected in the adductor muscle of $C$. gigas spat ( $10^{8}$ viral DNA copies per oyster). All oysters received thus the same 
amount of OsHV-1 DNA at the same time (Schikorski et al., 2011a, 2011b). Six spat were collected at $2 \mathrm{~h}, 6 \mathrm{~h}$, and $28 \mathrm{~h}$ post viral injection for further analysis.

C. gigas spat (NSI 01/15) produced in 2014 at the Ifremer hatchery located in Argenton (Brittany, France) and then reared at the Ifremer facilities in Bouin (Vendée, France) were used as unchallenged control for immunohistochemistry and the in situ hybridization assays.

\section{Polyclonal antibody production}

Two putative membrane proteins encoded by ORF 25 and ORF 72 and one putative apoptosis inhibitor encoded by ORF 87, were selected to analyze the tissue distribution of viral proteins during an experimental infection. Based on a protein sequence analysis, the two first proteins might correspond to structural proteins located on the surface of the viral envelope, and therefore play a key role in the interaction between the virus and the host. This interaction especially occured in the earliest stage of infection during the attachment and the entry of the virus into host cell. The second targeted viral protein was a putative apoptosis inhibitor which might alter host immune response. Segarra et al. (2014) showed that mRNA corresponding to these three ORFs were expressed at high levels by $28 \mathrm{~h}$ post viral challenge and we hypothesized that the proteins might be strongly produced, increasing the ability to detect them. Moreover, these mRNA were expressed early during OsHV-1 infection in experimental conditions.

Polyclonal antibodies targeting proteins encoded by ORFs 25, 72, and 87 were produced by ProteoGenix (Schiltigheim, France). Briefly, the partial cDNA of each ORF was cloned in pET43.1a vector in order to express the protein with His tag in N-terminal position (cloning strategy: $\mathrm{Ndel} / \mathrm{XhoI}$ ). After purification of the three recombinant proteins, each one was then injected to two different rabbits. The post-immune sera of the six rabbits were individually collected and polyclonal antibodies were separately purified using protein A affinity chromatography (ProteoGenix). 


\section{Antibody treatment using proteins extracted from non-challenged oysters}

Polyclonal antibodies against viral proteins were treated using proteins extracted from nonchallenged oysters (considered as non-infected animals) to reduce non-specific epitope interactions, i.e. binding of primary antibodies to oyster proteins. All oyster tissues were mashed with TRIS EDTA buffer $\mathrm{pH} 8.3$ and $10 \mu \mathrm{L}$ Protease Inhibitor Mix (GE Healthcare) in a Precellys ${ }^{\circledR}$ homogenizer. After centrifugation at $5,000 \mathrm{~g}$ during $5 \mathrm{~min}$ at $4^{\circ} \mathrm{C}$, proteins were solubilized in a buffer containing 6M Urea, 2M Thiourea, and 4\% CHAPS. Proteins were quantified with the Micro BCA Protein Assay Kit (Life Technologies) according to the manufacturer's protocol. Polyclonal antibodies were incubated with proteins extracted from non-challenged oysters $(20 \mathrm{mg} / \mathrm{mL})$ and Tris-Buffered Saline with additional 0.1\% Tween 20 (TBST) under gentle stirring at $4^{\circ} \mathrm{C}$ overnight. More precisely, the mixture included $15 \mu \mathrm{L}$ of polyclonal antibodies (antibodies against proteins encoded by ORF 25,72 , or 87 ), $110 \mu \mathrm{L}$ proteins extracted from non-challenged oysters, and $300 \mu \mathrm{L}$ TBST. After incubation, the mixture was centrifuged at $16,000 \mathrm{~g}$ during $15 \mathrm{~min}$ at $4^{\circ} \mathrm{C}$ and the supernatant was placed in a Falcon ${ }^{\circledR}$ tube. To obtain final primary antibody concentrations of 1:250 (antibody against protein encoded by ORF 72) and 1:100 (antibodies against proteins encoded by ORF 25 and ORF 87$), 3.325 \mu \mathrm{L}$ and $1.075 \mu \mathrm{L}$ of $1 \mathrm{X}$ PBS with $0.5 \%$ of dried skim milk were added, respectively. This solution was then left on tissue sections during the immunohistochemistry assay.

\section{Immunohistochemistry assay (IHC)}

Oyster samples were preserved in Davidson's fixative (22\% formaldehyde, $33 \%$ ethanol 95, $12 \%$ glycerol, $33 \%$ of $0.2 \mu \mathrm{M}$ filtered seawater, and $10 \%$ acetic acid) until $48 \mathrm{~h}$ and then stored in ethanol before to be embedded in paraffin wax blocks. Seven micrometer sections were cut and mounted on to silane-coated slides (Sigma). The tissues were deparaffinized in xylene, treated with absolute ethanol, and treated in a methanol bath containing $0.3 \%$ of hydrogen peroxide during $1 \mathrm{~h}$ in the dark at room temperature to inactive endogenous peroxidases. After two washes in $1 \mathrm{X}$ PBS 10min, 
potential sites of non-specific interaction were blocked using $6 \%$ dried skim milk dissolved in $1 \mathrm{X}$ PBS during 30min at room temperature. The slides were incubated overnight at $4{ }^{\circ} \mathrm{C}$ with the polyclonal primary antibody diluted in $1 \mathrm{X}$ PBS, supplemented with $0.5 \%$ of dried skim milk $(1: 250$ for anti-ORF 72, and 1:100 for anti-ORF 25 and anti-ORF 87). Unbound primary antibodies were removed by five washes in $1 \mathrm{X}$ PBS. Primary antibodies were detected using a peroxidaseconjugated antibody against rabbit $\operatorname{IgG}$ (A0545, Sigma) diluted in 1:400 in $1 \mathrm{X}$ PBS with $0.5 \%$ of dried skim milk for $1 \mathrm{~h}$ at room temperature. Unbound secondary antibodies were removed by five washes in 1X PBS. Ten milligrams of diaminobenzidine tetrahydrochloride (Sigma) was dissolved in $15 \mathrm{~mL}$ of $1 \mathrm{X}$ PBS with $12 \mu \mathrm{L}$ of hydrogen peroxide. This solution was added on each tissue section and incubation was carried out $10 \mathrm{~min}$ in the dark at room temperature. The reaction was stopped with two 1X PBS washes. Sections were stained for 20s in Brillant Cresyl Blue (RAL diagnostics), dehydrated in ethanol and cleared in xylene before to be mounted in Eukitt resin for microscopy observation. Negative controls corresponded to tissue sections without primary antibodies.

A system to score levels of IHC staining in tissues was established: - = no signal, $+=$ low signal, ++ $=$ moderate signal, and $+++=$ high signal. This approach was used by Monaghan et al. (2015) to examine the early infection stages of koi herpesvirus (KHV) in carp Cyprinus carpio L. using ISH.

\section{In situ hybridization (ISH)}

Histological sections were treated as previously described (Lipart and Renault, 2002) with some modifications and used by Corbeil et al. (2015). Briefly, the tissues were deparaffinized in xylene, treated with absolute ethanol, and incubated in a methanol bath containing $0.3 \%$ of hydrogen peroxide during $1 \mathrm{~h}$ in the dark at room temperature to inactive endogenous peroxidases. After two washes in $1 \mathrm{X}$ PBS $10 \mathrm{~min}$, tissues were digested with $100 \mu \mathrm{g} / \mathrm{mL}$ proteinase $\mathrm{K}$ at $37^{\circ} \mathrm{C}$ for $10 \mathrm{~min}$ and the reaction was then stopped with ethanol. One hundred and twenty five microliters of a 
hybridization solution (4X SSC, 50\% deionized formamide, 10\% dextran sulfate, 1X Denhardt's solution, $250 \mu \mathrm{g} / \mathrm{mL}$ yeast $\mathrm{t}-\mathrm{RNA}$, and $2.5 \mathrm{ng} / \mu \mathrm{L}$ of DNA probe) were used for each tissue section. The DNA probe targeted the $\mathrm{C}$ region of the OsHV-1 genome and was synthetized by incorporation of Digoxigenin-11-dUTP (Roche) into PCR products using the forward primer C2 (5, CTCTTTACCATGAAGATACCCACC $\left.3^{\prime}\right)$ and the reverse primer C6 (5', GTGCACGGCTTACCATTTTT 3'), previously designed by Renault and Arzul (2001). The denaturation of double stranded viral DNA and DNA probes was carry out at $95^{\circ} \mathrm{C}$ for $5 \mathrm{~min}$. Hybridization was then performed in a humid chamber at $42^{\circ} \mathrm{C}$ overnight. Slides were washed using a $0.2 \%$ bovine serum albumin dissolved in $1 \mathrm{X}$ SSC for $10 \mathrm{~min}$. A blocking solution containing $6 \%$ dried skim milk dissolved in $1 \mathrm{X}$ PBS, was left on the tissue sections for 30min at room temperature. Bound probes were detected with a peroxidase-conjugated antibody against Digoxigenin-POD, Fab fragments from sheep (Roche) diluted 1:50 in 1X PBS during $1 \mathrm{~h}$ at room temperature. Unbound antibodies were removed by five washes in $1 \mathrm{X}$ PBS. Ten milligrams of diaminobenzidine tetrahydrochloride (Sigma) was dissolved in $15 \mathrm{~mL}$ of $1 \mathrm{X}$ PBS with $12 \mu \mathrm{L}$ of hydrogen peroxide. This solution was added on each tissue section and incubation was carried out $10 \mathrm{~min}$ in the dark at room temperature. The reaction was stopped with 1X PBS washes. Sections were stained for 20s in Brillant Cresyl Blue (RAL diagnostics), dehydrated in ethanol and cleared in xylene before to be mounted in Eukitt resin for microscopy observation. A positive control consisted in C. gigas spat known as infected by OsHV-1 and which was positive in OsHV-1 DNA detected by real-time PCR.

\section{DNA extraction and OsHV-1 DNA detection by real-time PCR}

The DNA was extracted from the mantle, gills, digestive gland, or adductor muscle of spat with the QIAmp DNA mini Kit (Qiagen) according to the manufacturer's instructions. DNA concentrations and DNA quality of samples were measured using a NanoDrop spectrophotometer (Thermo Fisher Scientifc) before to be diluted at $5 \mathrm{ng} / \mu \mathrm{L}$. Two real-time PCR based on SYBR ${ }^{\circledR}$ Green (Pepin et al., 
2008) and TaqMan ${ }^{\circledR}$ (Martenot et al., 2010) chemistries were used and targeted regions encoding a DNA polymerase catalytic subunit and a putative apoptosis inhibitor, respectively. A first real-time PCR (SYBR ${ }^{\circledR}$ Green chemistry) was used to quantify the viral DNA in oysters sampled during the infection challenge. Briefly, $5 \mu \mathrm{L}$ of DNA were added to the reaction mixture composed of $10 \mu \mathrm{L}$ of Brillant III ultra-Fast 99 SYBR $^{\circledR}$ Green Master Mix 10X (Agilent Technologies), $2 \mu \mathrm{L}$ of each primers OsHVDP For (forward) 5'-ATTGATGATGTGGATAATCTGTG-3' and OsHVDP Rev (reverse) 5'-GGTAAATACCATTGGTCTTGTTCC-3' (Webb et al., 2007) at the final concentration of $500 \mathrm{nM}$ each, and $1 \mu \mathrm{L}$ of distilled water. A second real-time PCR (TaqMan ${ }^{\circledR}$ chemistry) considered as more sensitive than the previous one, was used to quantify the viral DNA in nonchallenged oysters (NSI 01/15). The mix contained $5 \mu \mathrm{L}$ of DNA, $10 \mu \mathrm{L}$ of Brillant III Ultra-Fast

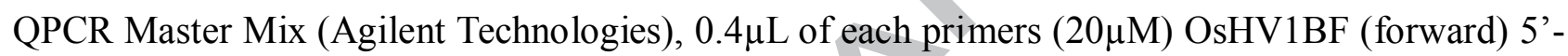
GTCGCATCTTTGGATTTAACAA-3' and B4 (reverse) 5'-ACTGGGATCCGACTGACAAC-3', $0.4 \mu \mathrm{L}$ of TaqMan ${ }^{\circledR}$ probe $(10 \mu \mathrm{M})$ 5'-TGCCCCTGTCATCTTGAGGTATAGACAATC-3' (Martenot et al., 2010), and 3.8 $\mathrm{L}$ of distilled water. The amplification was performed in duplicate for each sample and accomplished using a Mx3000P real-time PCR thermocycler (Agilent). The SYBR ${ }^{\circledR}$ PCR conditions consisted of 1 cycle at $95^{\circ} \mathrm{C}$ for $3 \mathrm{~min}, 40$ cycles of amplification at $95^{\circ} \mathrm{C}$ for $5 \mathrm{~s}$, $60^{\circ} \mathrm{C}$ for $20 \mathrm{~s}$, and followed by a dissociation stage $\left(95^{\circ} \mathrm{C}\right.$ for $1 \mathrm{~min}, 60^{\circ} \mathrm{C}$ for $30 \mathrm{~s}$, and $95^{\circ} \mathrm{c}$ for $\left.30 \mathrm{~s}\right)$.

The TaqMan ${ }^{\circledR}$ PCR conditions were 1 cycle at $95^{\circ} \mathrm{C}$ for $3 \mathrm{~min}, 40$ cycles of amplification at $95^{\circ} \mathrm{C}$ for $10 \mathrm{~s}, 60^{\circ} \mathrm{C}$ for $20 \mathrm{~s}$. Assays included a standard curve and a negative control $(5 \mu \mathrm{L}$ of distilled water instead of the $5 \mu \mathrm{L}$ of sample DNA). Results were expressed in viral DNA copies in one nanogram of total DNA.

\section{Statistical analysis}

The Kappa value was used to compare virus detection between organs and techniques (ISH and IHC). The Kappa (K) value was calculated with respect to the following formula: $K=(\operatorname{Pr}(\mathrm{a})$ - 
$\operatorname{Pr}(\mathrm{e})) /(1-\operatorname{Pr}(\mathrm{e}))$ where $\operatorname{Pr}(\mathrm{a})$ is the relative observed agreement and $\operatorname{Pr}(\mathrm{e})$ is the hypothetical probability of chance agreement. The interpretation of Kappa value is based on the numeric scale proposed by Landis and Koch (Landis and Koch, 1977): <0, poor agreement ; 0 to 0.20 , slight agreement ; 0.21 to 0.40 , fair agreement ; 0.41 to 0.60 , moderate agreement ; 0.61 to 0.80 substantial agreement, and 0.81 to 1 , almost perfect agreement).

For the technique comparison, an animal was considered positive by a technique if at least two organs presented a brown precipitate (positive signal). The distribution of immunohistochemical staining between gills, adductor muscle, labial palps, mantle, digestive gland, and gonads was compared two by two. This statistical approach was previously used by Arzul et al. (2002) to compare the virus detection by ISH, IHC, and conventional PCR in gills, gonads, mantle, and adductor muscle in asymptomatic $C$. gigas adults.

\section{Results}

\section{OsHV-1 detection by IHC method}

The six infected spat sampled at $28 \mathrm{~h}$ post-infection and the ten unchallenged oysters (NSI 01/15) were used as positive and negative controls, respectively. Positive reactions (dark coloration corresponding to brown precipitates) were observed in the six infected spat essentially in cells localized in connective tissues of mantle, gills, digestive gland, labial palps, heart, and adductor muscle for the three anti-viral antibodies (Figure 1). Polyclonal antibodies against the putative IAP (ORF 87) showed brown staining in the nucleus of cells localized in the connective tissues and a cytoplasmic staining was obtained with antibodies against putative membrane proteins (ORF 25 and ORF 72). Ovocytes presented a positive signal using IHC whereas no signal was observed in the gonads of male oysters (Figure 1). No signal was obtained when the primary antibody was omitted

(Figure 2). Virus DNA amounts ranged from $3.15 \times 10^{5}$ to $1.22 \times 10^{6} \mathrm{DNA}$ copies $\mathrm{ng}^{-1}$ of total DNA 
extracted from mantle of the six infected spat sampled at $28 \mathrm{~h}$ post viral injection, suggesting high viral replication.

Most of the seven studied organs of the ten unchallenged spat (NSI 01/15) presented no signal (Table 1). Nonetheless, discrete signals were recorded in the unchallenged oysters especially in the intestine epithelia and the digestive tubules (Figure 3). Brown staining was also observed in some parts of mantle and gills and this detection varied with respect to the primary antibody used (Figure 3). Viral DNA was detected below the quantification limit of the real-time PCR in four of the ten unchallenged spat, especially within the digestive gland and gills (Table 1).

2. Comparison of OsHV-1 detection between immunohistochemistry and in situ hybridization

IHC results from the six spat sampled at $28 \mathrm{~h}$ post injection were compared with those obtained in ISH with DNA (C2/C6) and RNA (viral mRNA encoded by ORF 87) probes (Table 2, Figure 3). RNA and DNA detection results were obtained from (Segarra et al., 2016). Results from the six spat (animal 13 to animal 18) and the ten unchallenged spat (NSI 01/15) were used to compare virus detection between ISH (DNA probe) and IHC. An oyster was considered positive if at least two organs among gills, labial palps, adductor muscle, digestive gland, mantle, and heart contained brown precipitates (Figure 4). The Kappa value was 0.75 and corresponded to a substantial agreement between the two techniques.

3. Detection and tissue distribution of OsHV-1 proteins during an experimental infection 
A system to score levels of IHC staining in tissues was used to investigate the organ distribution of the three OsHV-1 proteins in eighteen spat sampled at $2 \mathrm{~h}, 6 \mathrm{~h}$, and $28 \mathrm{~h}$ post viral injection (Table 3 ). Gills, mantle, and digestive tissue were preferentially stained in comparison with gonads, labial palps, and the adductor muscle. For infected spat, positive signals increased from $2 \mathrm{~h}$ to $6 \mathrm{~h}$ postinjection. The proportion of tissue with "few signals" and "many signals" decreased from $34 \%$ to $19 \%$ and increased from $10 \%$ to $49 \%$ in $6 \mathrm{~h}$, respectively (Figure 5 ). At $28 \mathrm{~h}$ post viral injection, all organs presented labeled cells (except some gonads) and 67\% of them had "many signals" (Figure $5)$.

Results from these eighteen animals and the ten unchallenged spat (NSI 01/15) were classified as dichotomous response (0: no signal and 1: positive signal) before to compare two by two the six organs with the Kappa value: gills, mantle, adductor muscle, labial palps, digestive gland, and gonads (Table 4). As the heart was often absent on tissue sections, this organ was not included in the analysis. The Kappa values were compared with the Landis and Koch numeric scale and a moderate agreement to an almost perfect agreement were obtained for gill, mantle, adductor muscle, and labial palps with antibodies targeting proteins encoded by ORF 25 and ORF 72 . On the contrary, a poor to a fair agreement were observed for the digestive gland and gonads with the same antibodies. Finally, a fair to a substantial agreement were obtained for gills, mantle, adductor muscle, and labial palps with antibodies targeting protein encoded by ORF 87. Weak Kappa values were observed when organs were compared to gonad since a positive signal was only detected in female oysters.

A similar analyze was performed to compare two by two results obtained using the three antibodies against viral proteins for each organ with the Kappa value (Table 5). A moderate agreement to an almost perfect agreement were obtained for mantle, gills, adductor muscle, and labial palps using the three antibodies against viral proteins contrary to the gonad and the digestive gland.

\section{Discussion}


The OsHV-1 replication cycle is not completely elucidated, and little information is available for the detection and distribution of viral proteins during infection. In the present work, experimentally infected spat suffered high mortality $(100 \%$ at $96 \mathrm{~h})$ after viral intra-muscular injection. Additionally, the increase in DNA OsHV-1 copy number in the mantle of experimentally infected spat during the experiment support that high viral replication occurred. The relationship between high viral DNA detection and the virus replication, followed by spat mortality was previously reported (Oden et al., 2011; Schikorski et al., 2011a, 2011b). Very low amounts of OsHV-1 DNA were also detected in four oysters among the ten unchallenged spat (NSI 01/15) in digestive gland, or gills. These oysters may have been previously exposed to OsHV-1, and the viral DNA detection may correspond to either a persistent or recently acquired infection. This hypothesis was supported by several authors since viral DNA or proteins were detected in apparently healthy juvenile or adult Pacific oysters (Arzul et al., 2002; Barbosa-Solomieu et al., 2005, 2004; Martenot et al., 2011; Oden et al., 2011). Results from these studies highlight the difficulty in identifying OsHV-1 uninfected spat. However, even if many improvements in molecular biology allowed the detection of pathogen agents presented in low amounts, the absence of positive signal by real-time PCR do not exclude the presence of pathogens. More recently, several authors highlighted the difficulty to include proper validation in diagnostic assays for OsHV-1 (Burge et al., 2016; Carnegie et al., 2016).

To study OsHV-1 protein localization on histological sections, highly infected animals were first used to optimize the chance of protein detection. Schikorski et al. (2011a) and Segarra et al. (2014) reported that high viral replication was observed around $26 \mathrm{~h}$ after intra-muscular injection of virus suspension in experimental assays before high mortality occurred. Thus, the six spat sampled at $28 \mathrm{~h}$ post viral suspension injection were selected to test antibodies targeting proteins encoded by ORFs 25, 72, and 87. These animals showed strong positive reactions with numerous stained cells in different organs. Positive signals for the antibodies against the putative apoptosis inhibitor was detected in the nucleus of cells in connective tissue of mantle, gills, digestive gland, labial palps, 
heart, adductor muscle, and female gonad. These observations were in accordance with those previously obtained using ISH or IHC techniques (Arzul et al., 2002; Corbeil et al., 2015; Lipart and Renault, 2002). Lipart and Renault (2002) reported that the viral DNA distribution was mainly reported in connective tissue of several organs and these results were confirmed by Corbeil et al. (2015) at viral DNA and RNA levels. However, the two putative membrane proteins targeted in the present investigation were preferentially detected in the cytoplasm of cells localized in the epithelia of mantle, gills, labial palps, and digestive gland. Arzul et al. (2002) observed also a positive signal in gonads and epithelial cells of gills in asymptomatic $C$. gigas adults by ISH. Protein detection in the epithelia were reported for equine herpesvirus 1 (EHV-1) (Easton et al., 2009; Szeredi et al., 2003) and human herpesvirus 8 (HHV-8) (Chagas et al., 2006). These viral proteins were also observed in cells involved in immune system, such as mononuclear cells (Ojok and Brown, 1996), lymphoid cells (Chagas et al., 2006), or monocytes (Szeredi et al., 2003). Some of labelled cells observed in the different spat organs might be correspond to hemocytes; cells implicated in the oyster defense response.

Immunohistochemistry staining with the three antibodies was generally grouped in a part of the tissue and the viral protein distribution was heterogenous in the different studied organs of oysters. In addition, the viral protein detection was often associated to enlarged nuclei showing abnormal chromatin patterns which were previously described during OsHV-1 infection in histological and transmission electron microscopic examination (Comps and Cochennec, 1993; Corbeil et al., 2015; Hine et al., 1992; Nicolas et al., 1992; Renault et al., 1994a, 1994b). Additionally, a moderate agreement to an almost perfect agreement were obtained for five studied organs (mantle, gills, adductor muscle, and labial palps) using the three polyclonal antibodies. Taken together, these observations suggested an accurate recognition of the viral targets by the three antibodies. In order to limit cross-reactions, antibodies were treated using proteins extracted from unchallenged oysters prior to be used in IHC. The specificity of the three antibodies was also investigated by a western 
blotting approach using denatured proteins extracted from experimentally infected and uninfected spat. No clear difference between the two conditions was observed (data not shown). Antibodies were produced from recombinant proteins and they might recognize conformational epitopes which were absent in denatured conditions. No accordance could be observed between results obtained from IHC and western blotting approaches (Forsström et al., 2015).

Results from six infected oysters (sampled at $28 \mathrm{~h}$ post viral injection) and ten unchallenged (NSI 01/15) spat obtained by ISH and IHC were compared and a substantial agreement was observed between the two techniques. Few signals are reported in the digestive gland of infected spat with the RNA probe targeting ORF $87 \mathrm{mRNA}$, suggesting digestive gland is not a main site of viral replication. On the contrary, viral DNA, RNA, and proteins were detected in gills, mantle, heart, adductor muscle, and labial palps, hypothesizing that viral replication might be preferentially realized in these organs at $28 \mathrm{~h}$ post viral injection.

Differences were observed in terms of tissue distribution and cell localization between the three antibodies used, and the cellular distribution might be linked to the function of the viral proteins. Putative membrane proteins (structural proteins) were mainly detected in the cytoplasm of epithelial cells and the putative apoptosis inhibitor as a functional protein was mainly present in cell nuclei in connective tissues of several organs/tissues. Moreover, the two antibodies targeting putative membrane proteins showed stained cells localized in the epithelium of intestine, labial palps, mantle, and gills, and pose some question about the role of epithelia in the viral replication cycle. Epithelia might be considered to a viral entry or a way used to release viral proteins or viral particles. Recently, (Monaghan et al., 2015) suggested that the gills and the gut played an important role in the early pathogenesis of the KHV since viral DNA was detected only in these two organs $1 \mathrm{~h}$ after infection by cohabitation. Although Schikorski et al. (2011a) suggested that the digestive gland and the hemolymphatic system might be some ways of OsHV-1 entry, how the virus is able to infect 
its host and how it is released remain to be precisely elucidated. In the present study, it is not possible to precise the natural way of OsHV-1 entry since the viral suspension was injected in the haemolymphatic sinus of the adductor muscle. A major part of the viral suspension entered into the haemolymphatic system and viral particles might be transported by the haemolymph and hemocytes to different organs inducing viral infection. Additionally, some viral particles or viral components after cell degradation might be transported to epithelia and released outside the host by intraepithelial hemoctyes.

Viral protein detection in ovocytes or in connective tissue of gonad was observed in the present study and was previously reported by Arzul et al. (2002) in asymptomatic C. gigas adults using three different techniques, and by Corbeil et al. (2015). Cells localized near the gonad might be released with gametes in the sea water during the reproduction period and infected cells might be filtered by oysters which might be then infected by the virus. This phenomenon was previously suspected for the Chanel Catfish virus and the Oncorhynchus masou virus infecting the channel catfish and the landlocked masu salmon, respectively (Kimura et al., 1981; Nusbaum and Grizzle, 1987).

At $2 \mathrm{~h}$ and $6 \mathrm{~h}$ post injection, viral infection began and $28 \mathrm{~h}$ post injection corresponded to a high viral replication before mortality occurred (Schikorski et al., 2011a; Segarra et al., 2014). Stronger positive signals were obtained with antibodies targeting the putative apoptosis inhibitor than antibodies against putative membrane proteins. This observation might be linked to the function of the protein. Putative inhibitor apoptosis is used by gamma-herpesvirus family and the Kaposi's sarcoma-associated herpesvirus (KSHV) to persist in their host (Chudasama et al., 2015; Lagunoff and Carroll, 2003). The apoptosis constitutes an important immune defense for mollusk bivalves and was stimulated during an experimental infection by OsHV-1 (Jouaux et al., 2013; Renault et al., 2011). In return, OsHV-1 might manipulate apoptosis to escape to immune system of the host and 
continue its replication as reported for other herpesviruses (Guo et al., 2015). The protein encoded by ORF 87 contains a BIR domain which might inhibit apoptosis by acting as direct inhibitors of caspases. Corbeil et al. (2015) suggested that ORF 87 gene might be expressed quite early during the virus cycle, thus avoiding cell apoptosis and might explain the high viral protein detection.

At $6 \mathrm{~h}$ post viral injection, viral protein detection was almost at the maximal level with the three antibodies and all studied organs were positive at $28 \mathrm{~h}$ post injection excepted gonads. Recently, Monaghan et al. (2015) examined the early infection stages of KHV in experimentally infected carp and reported that a maximal DNA detection level took place between $8 \mathrm{~h}$ and $24 \mathrm{~h}$ post infection by cohabitation in most investigated tissues.

\section{Conclusion}

The IHC assay constitutes an appropriate technique for analyzing the localization and the distribution of OsHV-1 proteins in several tissues within a same individual during experimental challenges. Results obtained from ICH assays generate complementary data about the viral replication cycle and confirm the connective tissue tropism of the virus even if OsHV-1 proteins were detected in cells of epithelia in different tissues, suggesting that epithelia may play a role in OsHV-1 cycle.

Improvements of diagnostic methods to screen for the OsHV-1 presence including persistent infections have been recommended by Efsa (2015) and IHC appears of great interest to detect OsHV-1 quite early in oysters and subsequently contributes to the better understanding of the pathogenesis of the viral infection. 


\section{Acknowledgments}

The authors wish to thank the Ifremer hatchery team (LGPMM) in La Tremblade and the nursery team (LSPC) in Bouin for the production of Pacific oysters. We thank more particularly Dr. Lionel Dégremont to supply oysters for the viral challenge.

This work received financial support from the European projects "MOLecular TRacing of viral pathogens in AQuaculture" (MOLTRAQ) and "improving european mollusc aquaculture: disease detection and management" (Bivalife).

The viral infection was accomplished with spat produced within the framework of Bivalife European project (contract $\left.\mathrm{n}^{\circ} 266157\right)$. 


\section{References}

Aranguren, R., Costa, M., Novoa, B., Figueras, F., 2012. Detection of herpesvirus variant (OsHV-1 mu var) in Pacific oysters (Crassostrea gigas) in Spain and development of a rapid method for its differential diagnosis. URL http://www.fundacionoesa.es/trabajos-cientificos/detection-of-herpesvirus-variantoshv-1-mu-var-in-pacific-oysters-crassostrea-gigas-in-spain-and-development-of-a-rapid-methodfor-its-differential-diagnosis.

Arzul, I., Renault, T., Lipart, C., 2001. Experimental herpes-like viral infections in marine bivalves: demonstration of interspecies transmission. Dis. Aquat. Organ. 46, 1-6. doi:10.3354/dao046001

Arzul, I., Renault, T., Thébault, A., Gérard, A., 2002. Detection of oyster herpesvirus DNA and proteins in asymptomatic Crassostrea gigas adults. Virus Res. 84, 151-160. doi:10.1016/\$0168-1702(02)000072

Barbosa-Solomieu, V., Dégremont, L., Vázquez-Juárez, R., Ascencio-Valle, F., Boudry, P., Renault, T., 2005. Ostreid herpesvirus 1 (OsHV-1) detection among three successive generations of Pacific oysters (Crassostrea gigas). Virus Res. 107, 47-56. doi:10.1016/j.virusres.2004.06.012

Barbosa-Solomieu, V., Miossec, L., Vázquez-Juárez, R., Ascencio-Valle, F., Renault, T., 2004. Diagnosis of Ostreid herpesvirus 1 in fixed paraffin-embedded archival samples using PCR and in situ hybridisation. J. Virol. Methods 119, 65-72. doi:10.1016/j.jviromet.2004.02.007

Batista, F.M., Arzul, I., Pepin, J.-F., Ruano, F., Friedman, C.S., Boudry, P., Renault, T., 2007. Detection of ostreid herpesvirus 1 DNA by PCR in bivalve molluscs: a critical review. J. Virol. Methods 139, 1-11. doi:10.1016/j.jviromet.2006.09.005

Batista, F.M., López-Sanmartín, M., Boudry, P., Navas, J.I., Ruano, F., Renault, T., Fonseca, V.G., Leitão, A., 2014. Insights on the association between somatic aneuploidy and ostreid herpesvirus 1 detection in the oysters Crassostrea gigas, C. angulata and their F1 hybrids. Aquac. Res. n/a-n/a. doi:10.1111/are.12613

Bingham, P., Brangenberg, N., Williams, R., M, M., 2013. Investigation into the first diagnosis of ostreid herpesvirus type 1 in Pacific oysters. Surveillance 40, 20-24.

Burge, C.A., Friedman, C.S., 2012. Quantifying Ostreid herpesvirus (OsHV-1) genome copies and expression during transmission. Microb. Ecol. 63, 596-604. doi:10.1007/s00248-011-9937-1

Burge, C.A., Friedman, C.S., Getchell, R., House, M., Lafferty, K.D., Mydlarz, L.D., Prager, K.C., Sutherland, K.P., Renault, T., Kiryu, I., Vega-Thurber, R., 2016. Complementary approaches to diagnosing marine diseases: a union of the modern and the classic. Phil Trans R Soc B 371, 20150207. doi:10.1098/rstb.2015.0207

Burge, C.A., Griffin, F.J., Friedman, C.S., 2006. Mortality and herpesvirus infections of the Pacific oyster Crassostrea gigas in Tomales Bay, California, USA. Dis. Aquat. Organ. 72, 31-43.

Burge, C.A., Strenge, R.E., Friedman, C.S., 2011. Detection of the oyster herpesvirus in commercial bivalve in northern California, USA: conventional and quantitative PCR. Dis. Aquat. Organ. 94, 106-116.

Carnegie, R.B., Arzul, I., Bushek, D., 2016. Managing marine mollusc diseases in the context of regional and international commerce: policy issues and emerging concerns. Phil Trans R Soc B 371, 20150215. doi:10.1098/rstb.2015.0215

Chagas, C.A., Endo, L.H., Sakano, E., Pinto, G.A., Brousset, P., Vassallo, J., 2006. Detection of herpesvirus type 8 (HHV8) in children's tonsils and adenoids by immunohistochemistry and in situ hybridization. Int. J. Pediatr. Otorhinolaryngol. 70, 65-72. doi:10.1016/j.ijporl.2005.04.030

Chudasama, P., Konrad, A., Jochmann, R., Lausen, B., Holz, P., Naschberger, E., Neipel, F., Britzen-Laurent, N., Stürzl, M., 2015. Structural proteins of Kaposi's sarcoma-associated herpesvirus antagonize p53mediated apoptosis. Oncogene 34, 639-649. doi:10.1038/onc.2013.595

Clegg, T.A., Morrissey, T., Geoghegan, F., Martin, S.W., Lyons, K., Ashe, S., More, S.J., 2014. Risk factors associated with increased mortality of farmed Pacific oysters in Ireland during 2011. Prev. Vet. Med. 113, 257-267. doi:10.1016/j.prevetmed.2013.10.023 
Comps, M., Cochennec, N., 1993. A herpeslike virus from the European oyster Ostrea edulis L. J. Invertebr. Pathol. 201-203.

Corbeil, S., Faury, N., Segarra, A., Renault, T., 2015. Development of an in situ hybridization assay for the detection of ostreid herpesvirus type 1 mRNAs in the Pacific oyster, Crassostrea gigas. J. Virol. Methods 211, 43-50. doi:10.1016/j.jviromet.2014.10.007

Da Silva, P.M., Renault, T., Fuentes, J., Villalba, A., 2008. Herpesvirus infection in European flat oysters Ostrea edulis obtained from brood stocks of various geographic origins and grown in Galicia (NW Spain). Dis. Aquat. Organ. 78, 181-188.

Davison, A.J., Eberle, R., Ehlers, B., Hayward, G.S., McGeoch, D.J., Minson, A.C., Pellett, P.E., Roizman, B., Studdert, M.J., Thiry, E., 2009. The order Herpesvirales. Arch. Virol. 154, 171-177. doi:10.1007/s00705-008-0278-4

Davison, A.J., Trus, B.L., Cheng, N., Steven, A.C., Watson, M.S., Cunningham, C., Le Deuff, R.M., Renault, T., 2005. A novel class of herpesvirus with bivalve hosts. J. Gen. Virol. 86, 41-53. doi:10.1099/vir.0.80382-0

Domeneghetti, S., Varotto, L., Civettini, M., Rosani, U., Stauder, M., Pretto, T., Pezzati, E., Arcangeli, G., Turolla, E., Pallavicini, A., Venier, P., 2014. Mortality occurrence and pathogen detection in Crassostrea gigas and Mytilus galloprovincialis close-growing in shallow waters (Goro lagoon, Italy). Fish Shellfish Immunol. 41, 37-44. doi:10.1016/j.fsi.2014.05.023

Dundon, W.G., Arzul, I., Omnes, E., Robert, M., Magnabosco, C., Zambon, M., Gennari, L., Toffan, A., Terregino, C., Capua, I., Arcangeli, G., 2011. Detection of Type 1 Ostreid Herpes variant (OsHV-1 $\mu$ var) with no associated mortality in French-origin Pacific cupped oyster Crassostrea gigas farmed in Italy. Aquaculture 314, 49-52. doi:10.1016/j.aquaculture.2011.02.005

Easton, C., Fuentealba, N.A., Paullier, C., Alonzo, P., Carluccio, J., Galosi, C.M., 2009. Immunohistochemical and molecular detection of equine herpesvirus 1 in Uruguay. Rev. Sci. Tech. Int. Off. Epizoot. 28, 1085-1090.

Efsa, 2015. Oyster mortality13(6):4122 [59 pp.]. doi: 10.2903/j.efsa.2015.4122

Flamand, A., Babic, N., Coulon, P., 1998. Bases moléculaires du neurotropisme viral (rage et pseudo-rage). Virologie 2, 52-66.

Forsström, B., Bisławska Axnäs, B., Rockberg, J., Danielsson, H., Bohlin, A., Uhlen, M., 2015. Dissecting Antibodies with Regards to Linear and Conformational Epitopes. PLoS ONE 10. doi:10.1371/journal.pone.0121673

Francois, C., Joly, J., Garcia, C., Miossec, L., Arzul, I., Robert, M., Omnes, E., Chollet, B., Renault, T., 2009. Le Réseau REPAMO : un outil de surveillance de la santé des mollusques marins élevés et sauvages 5158.

Friedman, C.S., Estes, R.M., Stokes, N.A., Burge, C.A., Hargove, J.S., Barber, B.J., Elston, R.A., Burreson, E.M., Reece, K.S., 2005. Herpes virus in juvenile Pacific oysters Crassostrea gigas from Tomales Bay, California, coincides with summer mortality episodes. Dis. Aquat. Organ. 63, 33-41.

Grijalva-Chon, J.M., Castro-Longoria, R., Ramos-Paredes, J., Enríquez-Espinoza, T.L., Mendoza-Cano, F., 2013. Detection of a new OsHV-1 DNA strain in the healthy Pacific oyster, Crassostrea gigas Thunberg, from the Gulf of California. J. Fish Dis. 36, 965-968. doi:10.1111/jfd.12028

Guo, H., Kaiser, W.J., Mocarski, E.S., 2015. Manipulation of apoptosis and necroptosis signaling by herpesviruses. Med. Microbiol. Immunol. (Berl.) 204, 439-448. doi:10.1007/s00430-015-0410-5

Hine, P., Thorne, T., 1997. Replication of herpes-like viruses in haemocytes of adult flat oysters Ostrea angasi (Sowerby, 1871) : an ultrastructural study. Dis. Aquat. Organ. 29, 197-204.

Hine, P., Wesney, B., Besant, P., 1998. Replication of herpes-like viruses in larvae of the flat oyster Tiostrea chilensis at ambient temperatures. Dis. Aquat. Organ. 32, 161-171.

Hine, P., Wesney, B., Hay, B., 1992. Herpesvirus associated with mortalities among hatchery-reared larval Pacific oysters, C. gigas. Dis. Aquat. Organ. 12, 135-142.

Hwang, J.Y., Park, J.J., Yu, H.J., Hur, Y.B., Arzul, I., Couraleau, Y., Park, M.A., 2013. Ostreid herpesvirus 1 infection in farmed Pacific oyster larvae Crassostrea gigas (Thunberg) in Korea. J. Fish Dis. 36, 969972. doi:10.1111/jfd.12093 
Jee, B.Y., Lee, S.J., Cho, M.Y., Lee, S.J., Kim, J.W., Choi, S.H., Jeong, D.H., Kim, K.H., 2013. Detection of Ostreid Herpesvirus 1 from adult Pacific Oysters Crassostrea gigas Cultured in Korea. URL http://kpubs.org/article/articleMain.kpubs?articleANo=E1HKAL_2013_v16n2_131.

Jenkins, C., Hick, P., Gabor, M., Spiers, Z., Fell, S., Gu, X., Read, A., Go, J., 2013. Identification and characterisation of an ostreid herpesvirus-1 microvariant (OsHV-1 $\mu$-var) in Crassostrea gigas (Pacific oysters) in Australia. Dis. Aquat. Organ. 105, 109-26. doi:10.3354/dao02623

Jouaux, A., Lafont, M., Blin, J.-L., Houssin, M., Mathieu, M., Lelong, C., 2013. Physiological change under OsHV-1 contamination in Pacific oyster Crassostrea gigas through massive mortality events on fields. BMC Genomics 14, 590. doi:10.1186/1471-2164-14-590

Keeling, S.E., Brosnahan, C.L., Williams, R., Gias, E., Hannah, M., Bueno, R., McDonald, W.L., Johnston, C., 2014. New Zealand juvenile oyster mortality associated with ostreid herpesvirus 1-an opportunistic longitudinal study. Dis. Aquat. Organ. 109, 231-239. doi:10.3354/dao02735

Kimura, T., Yoshimizu, M., Tanaka, M., 1981. Studies on a new virus (OMV) from Oncorhynchus masou. II. Oncogenic nature. Fish Pathol. 15, 149-153.

Lagunoff, M., Carroll, P.A., 2003. Inhibition of apoptosis by the gamma-herpesviruses. Int. Rev. Immunol. 22, 373-399.

Landis, J.R., Koch, G.G., 1977. The measurement of observer agreement for categorical data. Biometrics 33, 159-174.

Le Deuff, R.M., Renault, T., 1999. Purification and partial genome characterization of a herpes-like virus infecting the Japanese oyster, Crassostrea gigas. J. Gen. Virol. 80 ( Pt 5), 1317-1322.

Lipart, C., Renault, T., 2002. Herpes-like virus detection in infected Crassostrea gigas spat using DIG-labelled probes. J. Virol. Methods 101, 1-10.

Lynch, S.A., Carlsson, J., Reilly, A.O., Cotter, E., Culloty, S.C., 2012. A previously undescribed ostreid herpes virus 1 (OsHV-1) genotype detected in the pacific oyster, Crassostrea gigas, in Ireland. Parasitology 139, 1526-1532. doi:10.1017/S0031182012000881

Martenot, C., 2013. Les variants du virus herpétique ostreid herpesvirus-1 (OsHV-1) chez l'huître creuse Crassostrea gigas. Virologie 17, 81-87. doi:10.1684/vir.2013.0481

Martenot, C., Denechère, L., Hubert, P., Metayer, L., Oden, E., Trancart, S., Travaillé, E., Houssin, M., 2015. Virulence of Ostreid herpesvirus $1 \mu \mathrm{Var}$ in sea water at $16^{\circ} \mathrm{C}$ and $25^{\circ} \mathrm{C}$. Aquaculture $439,1-6$. doi:10.1016/j.aquaculture.2015.01.012

Martenot, C., Fourour, S., Oden, E., Jouaux, A., Travaillé, E., Malas, J.P., Houssin, M., 2012. Detection of the OsHV-1 $\mu$ Var in the Pacific oyster Crassostrea gigas before 2008 in France and description of two new microvariants of the Ostreid Herpesvirus 1 (OsHV-1). Aquaculture 338-341, 293-296. doi:10.1016/j.aquaculture.2011.12.030

Martenot, C., Oden, E., Travaillé, E., Malas, J.-P., Houssin, M., 2011. Detection of different variants of Ostreid Herpesvirus 1 in the Pacific oyster, Crassostrea gigas between 2008 and 2010. Virus Res. 160, 2531. doi:10.1016/j.virusres.2011.04.012

Martenot, C., Oden, E., Travaillé, E., Malas, J.P., Houssin, M., 2010. Comparison of two real-time PCR methods for detection of ostreid herpesvirus 1 in the Pacific oyster Crassostrea gigas. J. Virol. Methods 170, 86-89. doi:10.1016/j.jviromet.2010.09.003

Monaghan, S.J., Thompson, K.D., Adams, A., Kempter, J., Bergmann, S.M., 2015. Examination of the early infection stages of koi herpesvirus (KHV) in experimentally infected carp, Cyprinus carpio L. using in situ hybridization. J. Fish Dis. 38, 477-489. doi:10.1111/jfd.12260

Moreau, P., Moreau, K., Segarra, A., Tourbiez, D., Travers, M.-A., Rubinsztein, D.C., Renault, T., 2015. Autophagy plays an important role in protecting Pacific oysters from OsHV-1 and Vibrio aestuarianus infections. Autophagy 0, 00-00. doi:10.1080/15548627.2015.1017188

Nicolas, J.-L., Comps, M., Cochennec-Laureau, N., 1992. Herpes-like virus infecting Pacific oyster larvae, Crassostrea gigas. Bull. Eur. Assoc. Fish Pathol. 11-13.

Nusbaum, K.E., Grizzle, J.M., 1987. Adherence of channel catfish virus to sperm and leukocytes. Aquaculture 65, 1-5. doi:10.1016/0044-8486(87)90265-1 
Oden, E., Martenot, C., Berthaux, M., Travaille, E., Malas, J.P., Houssin, M., 2011. Quantification of ostreid herpesvirus 1 (OsHV-1) in Crassostrea gigas by real-time PCR: Determination of a viral load threshold to prevent summer mortalities. Aquaculture 317, 27-31.

Ojok, L., Brown, C., 1996. An immunohistochemical study of the pathogenesis of virulent viscerotropic Newcastle disease in chickens. J. Comp. Pathol. 115, 221-227.

Paul-Pont, I., Dhand, N.K., Whittington, R.J., 2013a. Spatial distribution of mortality in Pacific oysters Crassostrea gigas: reflection on mechanisms of OsHV-1 transmission. Dis. Aquat. Organ. 105, 127138. doi:10.3354/dao02615

Paul-Pont, I., Dhand, N.K., Whittington, R.J., 2013b. Influence of husbandry practices on OsHV-1 associated mortality of Pacific oysters Crassostrea gigas. Aquaculture 412-413, 202-214. doi:10.1016/j.aquaculture.2013.07.038

Paul-Pont, I., Evans, O., Dhand, N.K., Rubio, A., Coad, P., Whittington, R.J., 2014. Descriptive epidemiology of mass mortality due to Ostreid herpesvirus-1 (OsHV-1) in commercially farmed Pacific oysters (Crassostrea gigas) in the Hawkesbury River estuary, Australia. Aquaculture 422-423, 146-159. doi:10.1016/j.aquaculture.2013.12.009

Peeler, E.J., Reese, R.A., Cheslett, D.L., Geoghegan, F., Power, A., Thrush, M.A., 2012. Investigation of mortality in Pacific oysters associated with Ostreid herpesvirus- $1 \mu$ Var in the Republic of Ireland in 2009. Prev. Vet. Med. 105, 136-143. doi:10.1016/j.prevetmed.2012.02.001

Pepin, J.F., Riou, A., Renault, T., 2008. Rapid and sensitive detection of ostreid herpesvirus 1 in oyster samples by real-time PCR. J. Virol. Methods 149, 269-276. doi:10.1016/j.jviromet.2008.01.022

Renault, T., 2006. Les virus infectant les bivalves marins. Virologie 10, 35-41.

Renault, T., Arzul, I., 2001. Herpes-like virus infections in hatchery-reared bivalve larvae in Europe: specific viral DNA detection by PCR. J. Fish Dis. 24, 161-167. doi:10.1046/j.1365-2761.2001.00282.x

Renault, T., Cochennec, N., Le Deuff, R.M., Chollet Bruno, 1994a. Herpes-like virus infecting Japanese oyster (C. gigas) spat. Bull. Eur. Assoc. Fish Pathol. 14, 64-66.

Renault, T., Faury, N., Barbosa-Solomieu, V., Moreau, K., 2011. Suppression substractive hybridisation (SSH) and real time PCR reveal differential gene expression in the Pacific cupped oyster, Crassostrea gigas, challenged with Ostreid herpesvirus 1. Dev. Comp. Immunol. 35, 725-735. doi:10.1016/j.dci.2011.02.004

Renault, T., Le Deuff, R.M., Cochennec, N., Maffart, P., 1994b. Herpesviruses associated with mortalities among Pacific oyster, Crassostrea gigas, in France-Comparative study. Rev. Médicale Vét. 145, 735742.

Renault, T., Le Deuff, R.M., Lipart, C., Delsert, C., 2000. Development of a PCR procedure for the detection of a herpes-like virus infecting oysters in France. J. Virol. Methods 88, 41-50.

Renault, T., Lipart, C., 1998. Diagnosis of herpes-like virus infections in oysters using molecular techniques. Presented at the Aquaculture and water : fish culture, shellfish culture and water usage.

Renault, T., Lipart, C., Arzul, I., 2001a. A herpes-like virus infecting Crassostrea gigas and Ruditapes philippinarum larvae in France. J. Fish Dis. 24, 369-376. doi:10.1046/j.1365-2761.2001.00300.x

Renault, T., Lipart, C., Arzul, I., 2001b. A herpes-like virus infects a non-ostreid bivalve species: virus replication in Ruditapes philippinarum larvae. Dis. Aquat. Organ. 45, 1-7.

Renault, T., Moreau, P., Faury, N., Pepin, J.-F., Segarra, A., Webb, S., 2012. Analysis of clinical ostreid herpesvirus 1 (malacoherpesviridae) specimens by sequencing amplified fragments from three virus genome areas. J. Virol. 86, 5942-5947. doi:10.1128/JVI.06534-11

Renault, T., Tchaleu, G., Faury, N., Moreau, P., Segarra, A., Barbosa-Solomieu, V., Lapègue, S., 2014. Genotyping of a microsatellite locus to differentiate clinical Ostreid herpesvirus 1 specimens. Vet. Res. 45, 3. doi:10.1186/1297-9716-45-3

Roque, A., Carrasco, N., Andree, K.B., Lacuesta, B., Elandaloussi, L., Gairin, I., Rodgers, C.J., Furones, M.D., 2012. First report of OsHV-1 microvar in Pacific oyster (Crassostrea gigas) cultured in Spain. Aquaculture 324-325, 303-306. doi:10.1016/j.aquaculture.2011.10.018 
Rosani, U., Varotto, L., Domeneghetti, S., Arcangeli, G., Pallavicini, A., Venier, P., 2014. Dual analysis of host and pathogen transcriptomes in ostreid herpesvirus 1-positive Crassostrea gigas. Environ. Microbiol. doi:10.1111/1462-2920.12706

Schikorski, D., Faury, N., Pepin, J.F., Saulnier, D., Tourbiez, D., Renault, T., 2011a. Experimental ostreid herpesvirus 1 infection of the Pacific oyster Crassostrea gigas: kinetics of virus DNA detection by qPCR in seawater and in oyster samples. Virus Res. 155, 28-34. doi:10.1016/j.virusres.2010.07.031

Schikorski, D., Renault, T., Saulnier, D., Faury, N., Moreau, P., Pepin, J., 2011b. Experimental infection of Pacific oyster Crassostrea gigas spat by ostreid herpesvirus 1: demonstration of oyster spat susceptibility. Vet. Res. 42, 27. doi:10.1186/1297-9716-42-27

Segarra, A., Baillon, L., Faury, N., Tourbiez, D., Renault, T., 2016. Detection and distribution of ostreid herpesvirus 1 in experimentally infected Pacific oyster spat. J. Invertebr. Pathol. 133, 59-65. doi:10.1016/j.jip.2015.11.013

Segarra, A., Baillon, L., Tourbiez, D., Benabdelmouna, A., Faury, N., Bourgougnon, N., Renault, T., 2014. Ostreid herpesvirus type 1 replication and host response in adult Pacific oysters, Crassostrea gigas. Vet. Res. 45. doi:10.1186/s13567-014-0103-x

Segarra, A., Pépin, J.F., Arzul, I., Morga, B., Faury, N., Renault, T., 2010. Detection and description of a particular Ostreid herpesvirus 1 genotype associated with massive mortality outbreaks of Pacific oysters, Crassostrea gigas, in France in 2008. Virus Res. 153, 92-99. doi:10.1016/j.virusres.2010.07.011

Szeredi, L., Aupperle, H., Steiger, K., 2003. Detection of equine herpesvirus-1 in the fetal membranes of aborted equine fetuses by immunohistochemical and in-situ hybridization techniques. J. Comp. Pathol. 129, 147-153.

Webb, S.C., Fidler, A., Renault, T., 2007. Primers for PCR-based detection of ostreid herpes virus-1 (OsHV-1): Application in a survey of New Zealand molluscs. Aquaculture 272, 126-139. doi:10.1016/j.aquaculture.2007.07.224

Whittington, R.J., Hick, P.M., Evans, O., Rubio, A., Alford, B., Dhand, N., Paul-Pont, I., 2015. Protection of Pacific oyster (Crassostrea gigas) spat from mortality due to ostreid herpesvirus 1 (OsHV-1 $\mu$ Var) using simple treatments of incoming seawater in land-based upwellers. Aquaculture 437, 10-20. doi:10.1016/j.aquaculture.2014.11.016 


\section{Figure Captions}

Figure 1. IHC results with polyclonal antibodies against OsHV-1 proteins encoded by ORF 72 (A) to $(\mathrm{F}), 87(\mathrm{G})$ to $(\mathrm{M})$, and $25(\mathrm{~N})$ to $(\mathrm{O})$ in experimentally infected spat. (A) gills. (B) and (C) mantle. (E) and (D) digestive tubules. (F) intestinal epithelium. (G) mantle. (H) connective tissue of the digestive gland (I) gills. (J) adductor muscle. (K) labial palps. (L) digestive tubules. (M) ovocytes. (N) gills. (O) mantle. Arrows indicate positive signals (brown staining). Zoom of a cytoplasmic staining (D) and nuclear staining (H).

Figure 2. IHC results with secondary antibody in experimentally infected spat (no primary antibody used). (A) mantle. (B) gills. (C) adductor muscle. (D) digestive gland. (E) heart. (F) labial palps. (G) male gonad. (H) ovocytes. $($ bar $=200 \mu \mathrm{M})$.

Figure 3. Organs without signal detection (A to C) and labelled cells (D to F) in unchallenged spat. (A, D) mantle, $(\mathrm{B}, \mathrm{E})$ gills, and $(\mathrm{C}, \mathrm{F})$ digestive tubules. Results from antibodies against putative apoptosis inhibitor (A to $\mathrm{C}$, and $\mathrm{E}$ ) and antibodies against putative membrane protein encoded by ORF 25 (D, F). Arrows indicate positive signals (brown staining).

Figure 4. Labelled cells (brown precipitates) obtained from antibodies against the putative apoptosis inhibitor encoded by ORF 87 (A, B) and the DNA probe targeting the C2/C6 region of the OsHV-1 genome $(C, D)$ within spat sampled at $28 \mathrm{~h}$ post viral injection in the gonadic area.

Figure 5. Stained distribution detected in the seven organs in respect with hours post viral injection for the three antibodies against viral proteins (A), antibodies against putative apoptosis inhibitor (B), and antibodies against putative membrane proteins (C and D). 


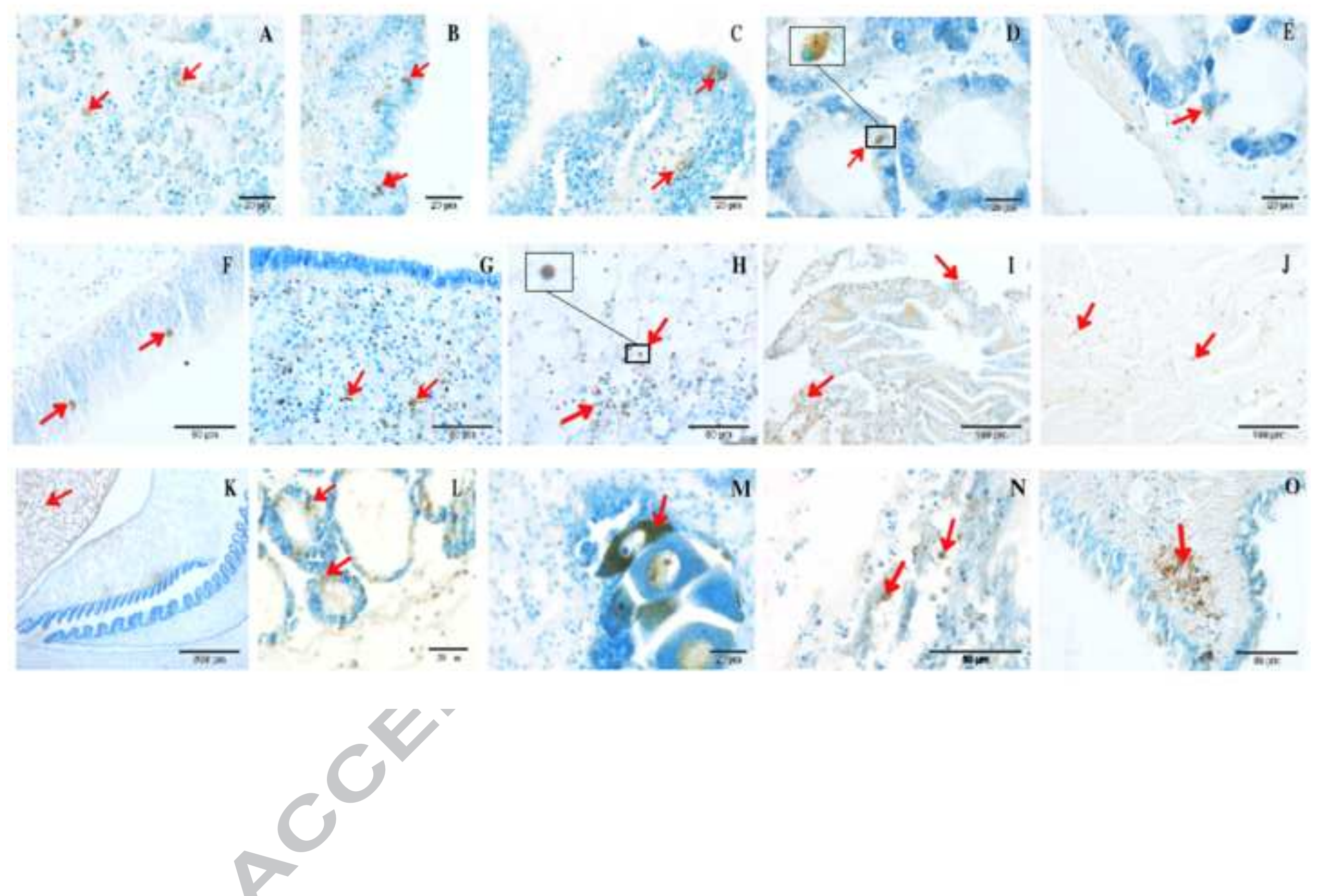



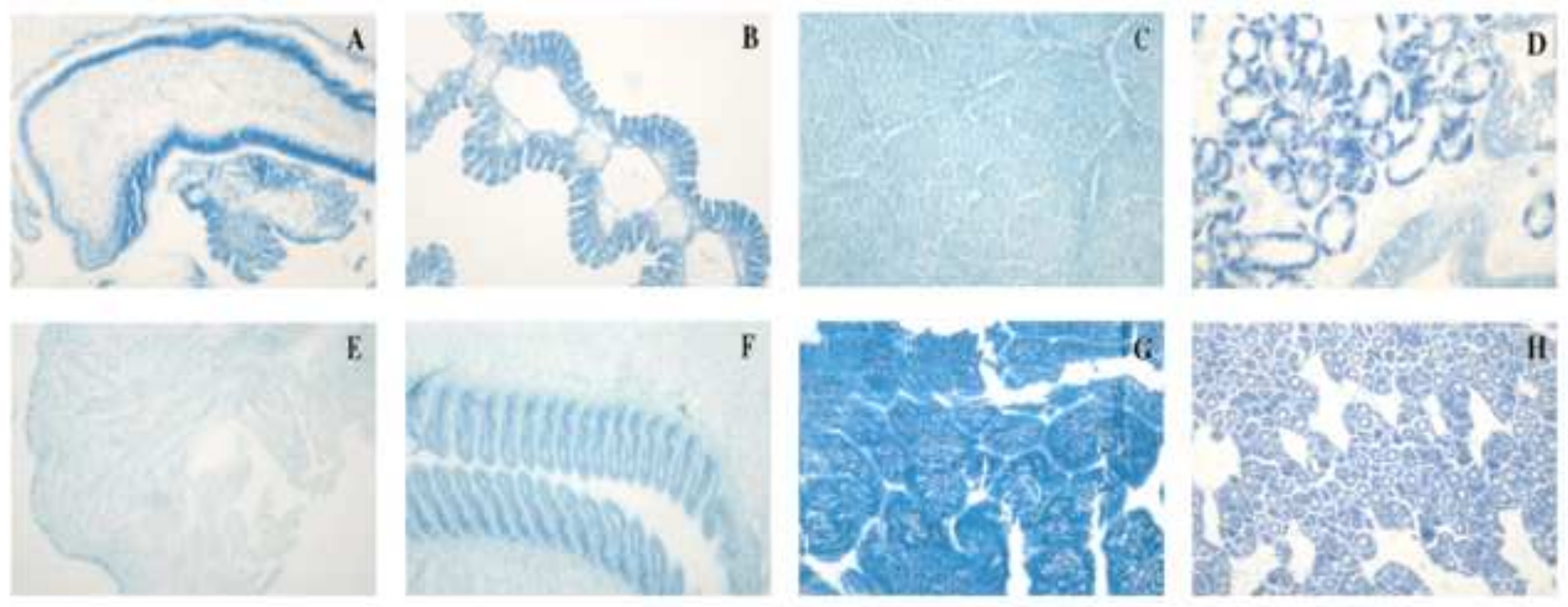

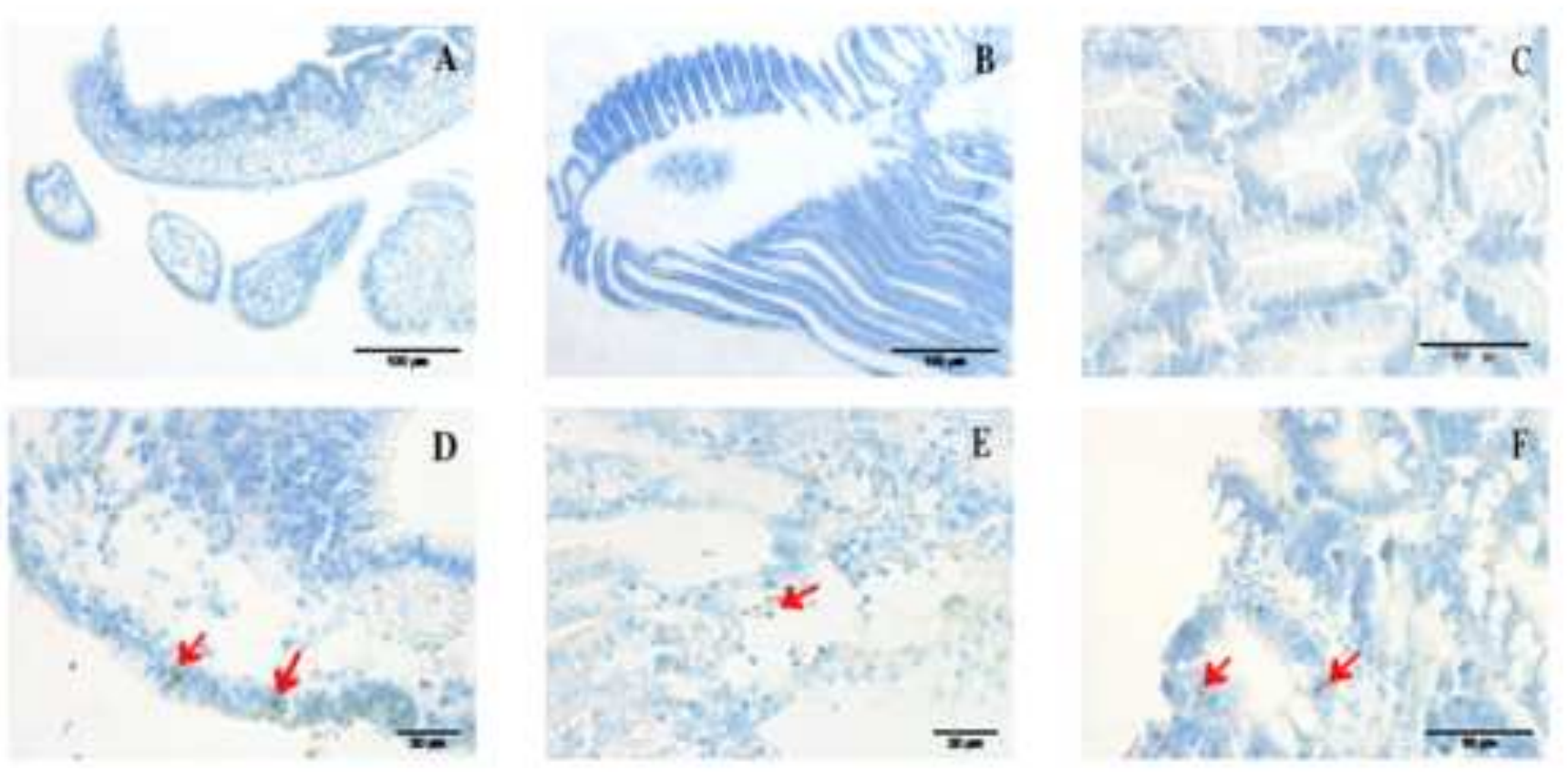

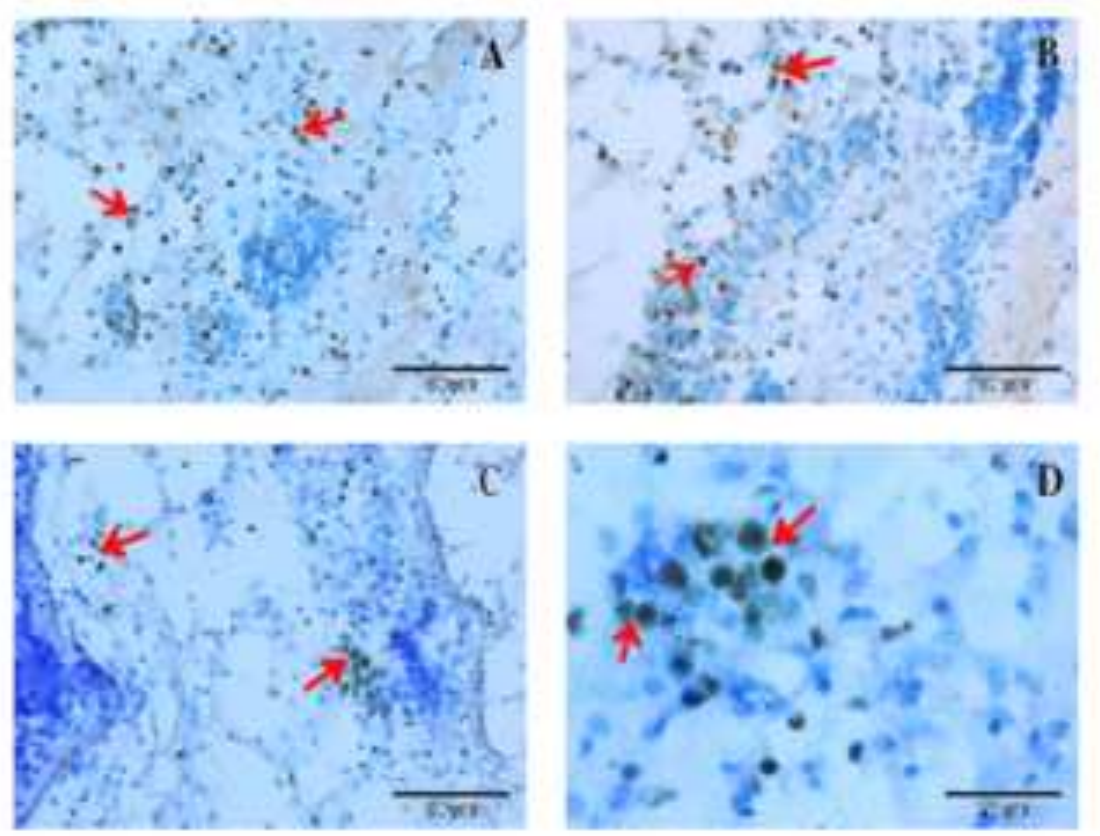


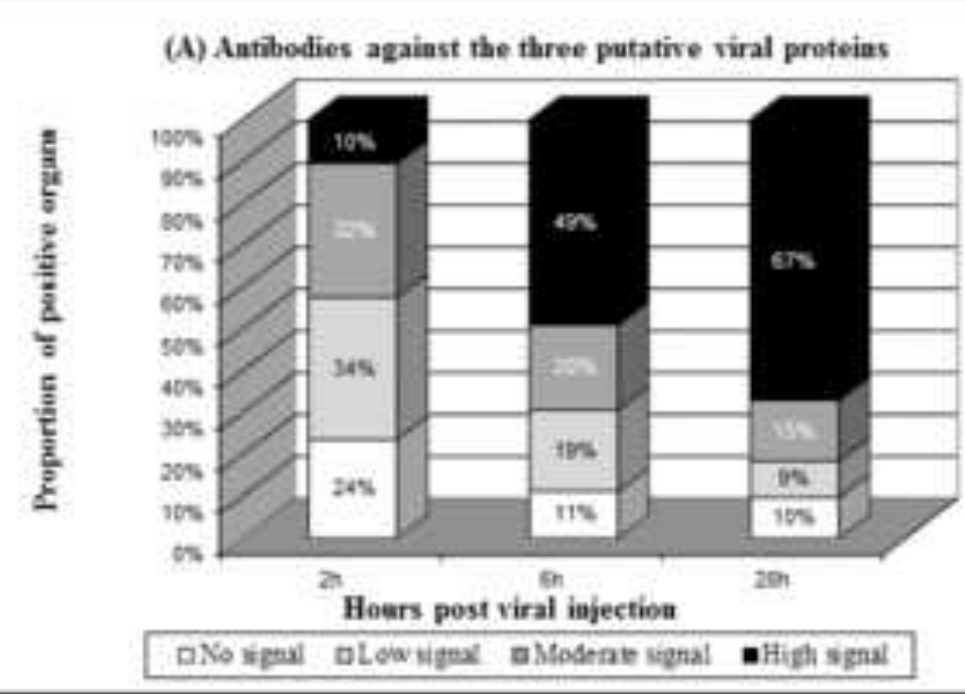

(C) Antibodies against putative membrase protein eacoded by ORF 25

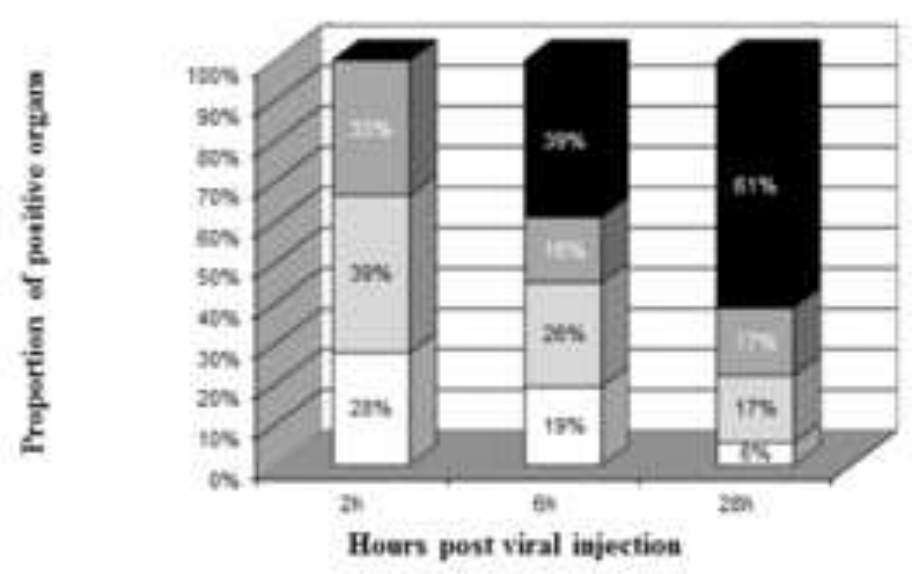

(B) Antibodies against putative apoptosis inhibitor eacoded by ORF 87

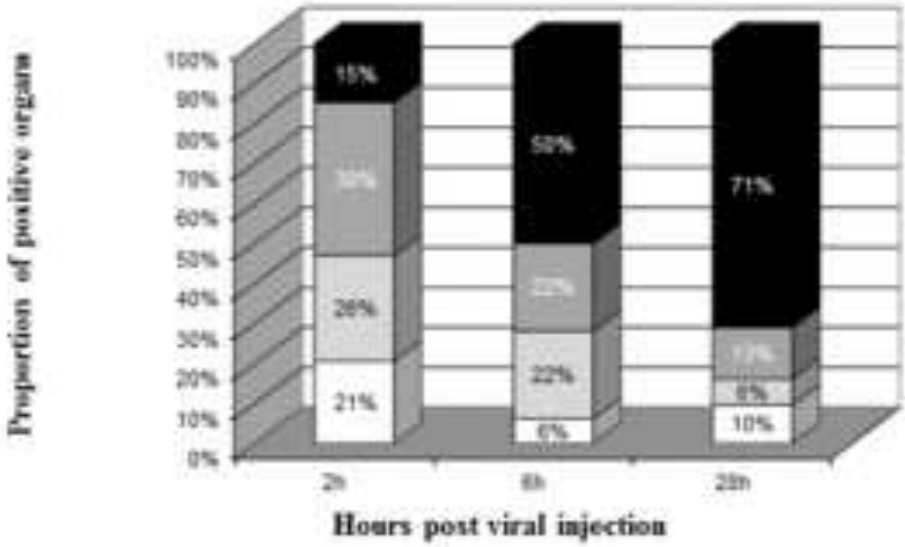

(D) Aatibodies against putative membrase protein eacoded by ORF 72

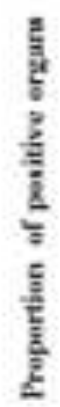

Hours post viral injection 
Table 1. IHC results using polyclonal antibodies against the three viral proteins encoded by ORFs 25, 72, and 87 in the ten unchallenged spat (NSI 01/15) and OsHV-1 DNA detection by real-time PCR.

\begin{tabular}{|c|c|c|c|c|c|c|c|c|c|c|c|c|c|c|c|c|c|c|c|c|c|c|}
\hline \multirow[b]{2}{*}{ Samples } & \multirow[b]{2}{*}{$\begin{array}{l}\text { Viral } \\
\text { DNA }\end{array}$} & \multicolumn{7}{|c|}{$\begin{array}{c}\text { Ab against the putative } \\
\text { protein encoded by ORF } 25\end{array}$} & \multicolumn{7}{|c|}{$\begin{array}{c}\text { Ab against the putative } \\
\text { protein encoded by ORF } 72\end{array}$} & \multicolumn{7}{|c|}{$\begin{array}{c}\text { Ab against the putative } \\
\text { protein encoded by ORF } 87\end{array}$} \\
\hline & & $\mathbf{M}$ & $\mathbf{G i}$ & DG & $\mathbf{H}$ & Go & $\mathbf{A M}$ & $\mathbf{L P}$ & $\mathbf{M}$ & Gi & DG & $\mathbf{H}$ & Go & $\mathbf{A M}$ & $\mathbf{L P}$ & $\mathbf{M}$ & $\mathbf{G i}$ & DG & $\mathbf{H}$ & Go & $\mathbf{A M}$ & $\mathbf{L P}$ \\
\hline Spat 1 & $+(\mathrm{DG})$ & + & + & + & + & - & - & + & + & - & + & - & - & - & - & + & - & + & + & - & - & - \\
\hline Spat 2 & - & - & - & - & 1 & - & - & - & - & - & - & 1 & - & - & - & - & + & - & 1 & - & - & - \\
\hline Spat 3 & - & - & - & + & 1 & - & - & - & - & - & - & 1 & - & - & - & - & - & - & 1 & - & - & - \\
\hline Spat 4 & $+(\mathrm{Gi})$ & - & - & - & - & - & - & - & - & - & + & - & - & - & - & -1 & - & + & - & - & - & - \\
\hline Spat 5 & - & - & - & - & 1 & - & - & - & - & - & + & 1 & - & - & - & - & - & + & 1 & - & - & - \\
\hline Spat 6 & - & - & - & + & - & - & - & - & - & - & + & 1 & - & - & - & + & - & + & 1 & - & - & - \\
\hline Spat 7 & - & - & - & + & - & - & - & - & - & - & + & 4 & - & - & - & + & + & + & - & - & - & - \\
\hline Spat 8 & $+(\mathrm{Gi})$ & - & ++ & + & - & - & - & - & + & - & + & - & - & - & - & + & + & + & - & - & - & - \\
\hline Spat 9 & $+(\mathrm{DG})$ & - & - & - & 1 & - & - & - & + & - & + & 1 & - & - & - & - & - & ++ & 1 & - & - & + \\
\hline Spat 10 & - & - & - & + & - & - & - & - & + & - & + & - & - & - & + & + & + & ++ & - & - & - & + \\
\hline
\end{tabular}

M, mantle; Gi, gills; DG, digestive gland; H, heart; G, gonad; AM, adductor muscle; LP, labial palps; /, tissue is absent on the section; -, no signal; +, low signal; ++, moderate signal. 
Table 2. OsHV-1 detection using IHC and ISH (DNA and RNA probes) techniques in the six same spat sampled at $28 \mathrm{~h}$ post viral injection.

\begin{tabular}{|c|c|c|c|c|c|c|c|c|c|c|c|c|c|c|c|c|c|c|c|c|c|}
\hline & \multicolumn{3}{|c|}{ Mantle } & \multicolumn{3}{|c|}{ Gills } & \multicolumn{3}{|c|}{$\begin{array}{l}\text { Digestive } \\
\text { gland }\end{array}$} & \multicolumn{3}{|c|}{ Heart } & \multicolumn{3}{|c|}{ Gonad } & \multicolumn{3}{|c|}{$\begin{array}{l}\text { Adducteur } \\
\text { muscle }\end{array}$} & \multicolumn{3}{|c|}{ Labial palps } \\
\hline & $\begin{array}{l}\mathbf{D} \\
\mathbf{N} \\
\mathbf{A}\end{array}$ & $\begin{array}{l}R \\
N \\
A\end{array}$ & $\begin{array}{l}\text { A } \\
\text { b }\end{array}$ & $\begin{array}{l}\text { D } \\
\text { N } \\
\text { A }\end{array}$ & $\begin{array}{l}\mathbf{R} \\
\mathrm{N} \\
\mathrm{A}\end{array}$ & $\begin{array}{l}\text { A } \\
\text { b }\end{array}$ & $\begin{array}{l}D \\
N \\
A\end{array}$ & $\begin{array}{l}\text { R } \\
\text { N } \\
\text { A }\end{array}$ & $\begin{array}{l}\text { A } \\
\text { b }\end{array}$ & $\begin{array}{l}D \\
N \\
A\end{array}$ & $\begin{array}{l}R \\
\mathbf{N} \\
\mathbf{A}\end{array}$ & $\begin{array}{l}\text { A } \\
\text { b }\end{array}$ & $\begin{array}{l}\text { D } \\
\text { N } \\
\text { A }\end{array}$ & $\begin{array}{l}\mathbf{R} \\
\mathbf{N} \\
\mathrm{A}\end{array}$ & $\begin{array}{l}\text { A } \\
\text { b }\end{array}$ & $\begin{array}{l}\text { D } \\
\text { N } \\
\text { A }\end{array}$ & $\begin{array}{l}\mathbf{R} \\
\mathbf{N} \\
\mathbf{A}\end{array}$ & $\begin{array}{l}\mathbf{A} \\
\mathbf{b}\end{array}$ & $\begin{array}{l}\text { D } \\
\text { N } \\
\text { A }\end{array}$ & $\begin{array}{l}\text { R } \\
\text { N } \\
\text { A }\end{array}$ & $\begin{array}{l}\text { A } \\
\text { b }\end{array}$ \\
\hline $\begin{array}{l}\mathrm{Sp} \\
\text { at } \\
13\end{array}$ & + & + & + & + & + & + & + & - & + & + & + & + & $/$ & - & $/$ & + & + & + & - & - & $/$ \\
\hline $\begin{array}{l}\text { Sp } \\
\text { at } \\
14\end{array}$ & + & - & + & + & - & + & - & - & + & / & I & + & / & - & 1 & + & - & + & / & / & / \\
\hline $\begin{array}{l}\mathrm{Sp} \\
\text { at } \\
15\end{array}$ & + & + & + & + & + & + & + & + & + & I & 1 & 1 & - & - & - & + & + & + & + & + & + \\
\hline $\begin{array}{l}S p \\
\text { at } \\
16\end{array}$ & + & + & + & + & + & + & + & & + & I & I & / & / & - & / & + & - & I & + & + & I \\
\hline $\begin{array}{l}\mathrm{Sp} \\
\text { at } \\
17\end{array}$ & + & + & + & + & + & + & + & - & + & + & + & + & / & - & $/$ & + & + & + & + & + & + \\
\hline $\begin{array}{l}\mathrm{Sp} \\
\text { at } \\
18\end{array}$ & + & + & + & + & + & + & + & - & + & $/$ & 1 & / & / & - & + & + & - & + & + & + & + \\
\hline
\end{tabular}

DNA, deoxyribonucleic acid; RNA, ribonucleic acid; Ab, antibodies; /, tissue is absent on the section; -, no signal; +, positive signals. 
Table 3. Immunohistochemistry results for the eighteen $C$. gigas spat collected at different times post viral injection with respect to the examined organs.

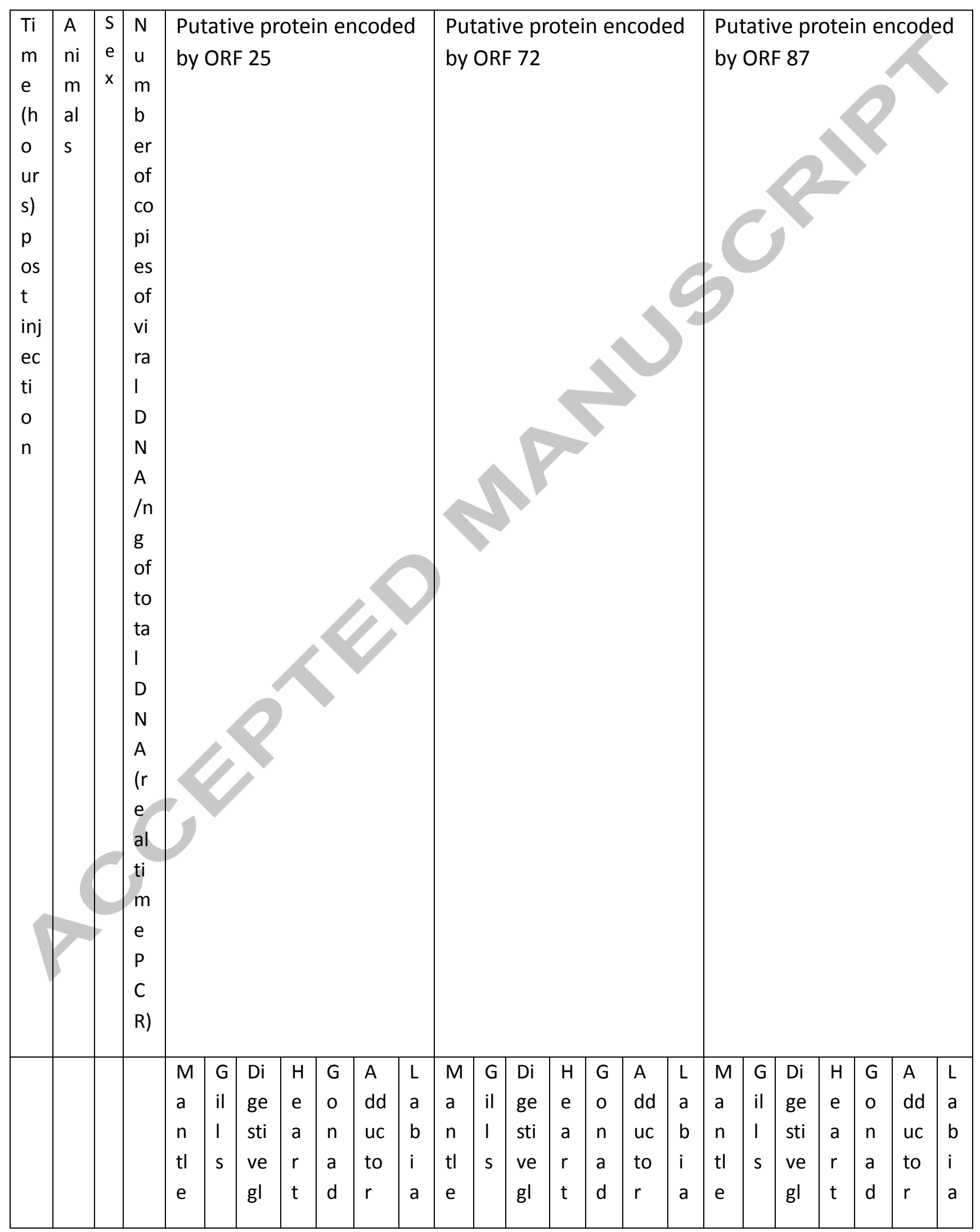




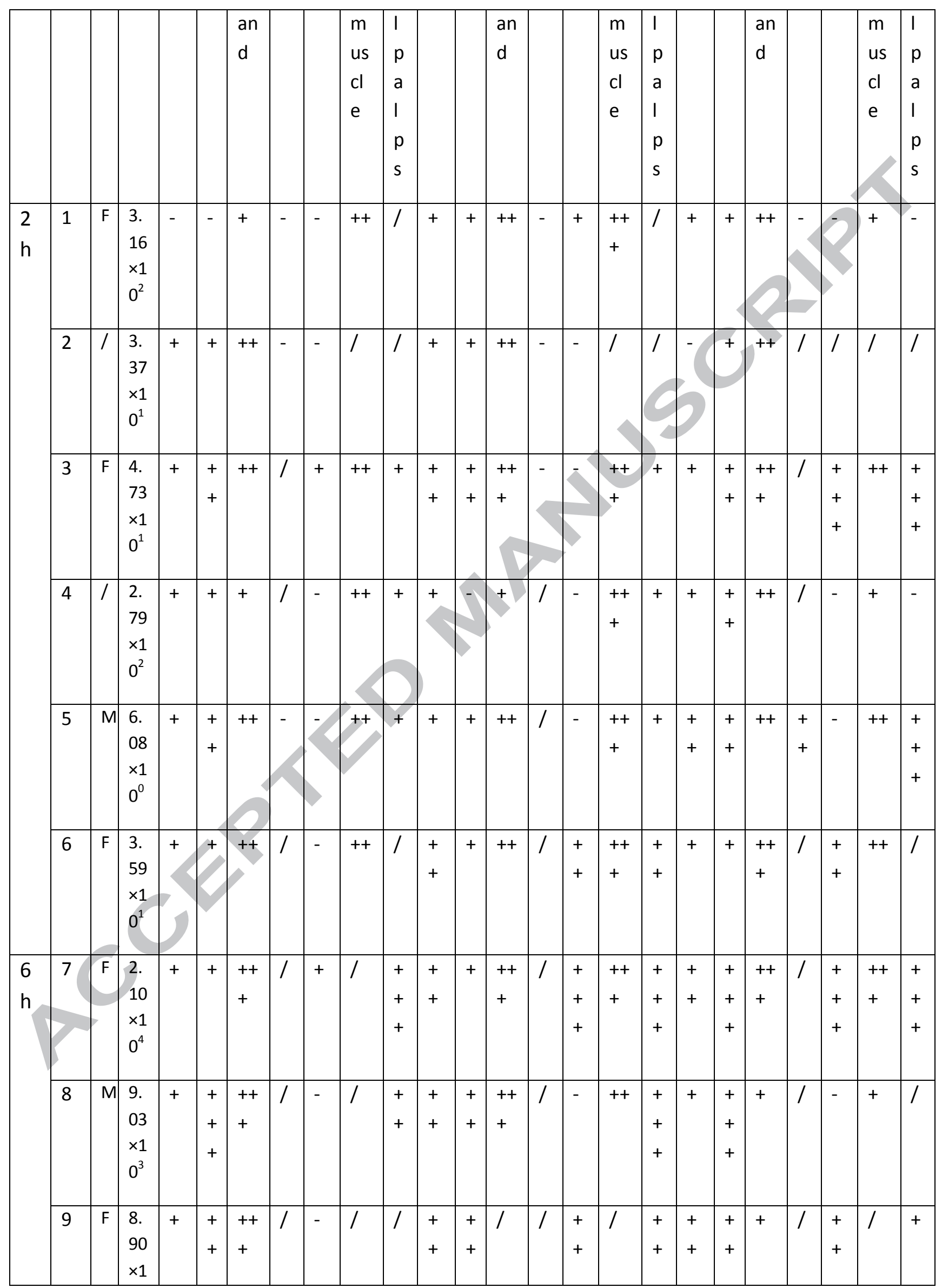




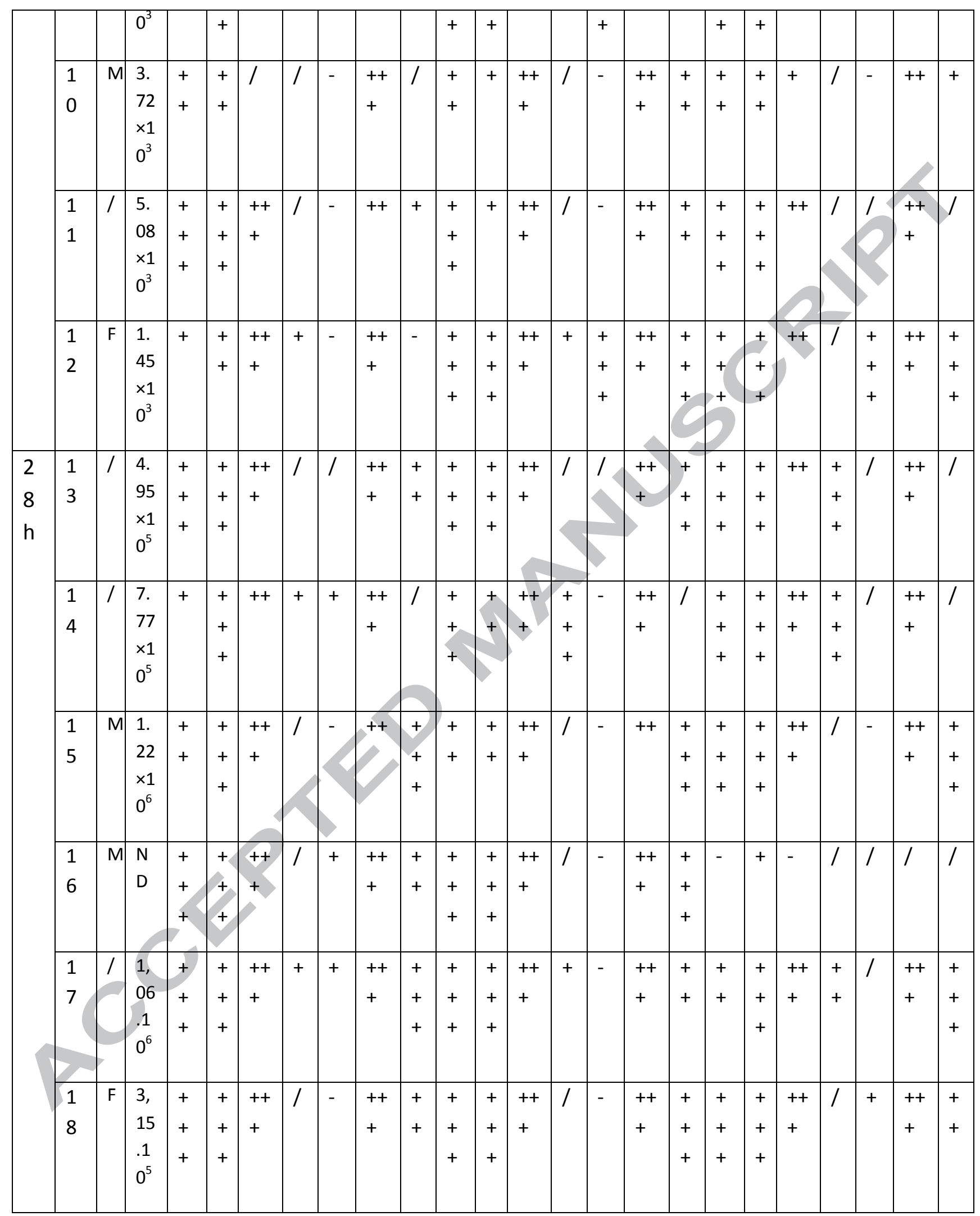


Table 4. Kappa values between organs.

\begin{tabular}{|l|c|c|c|}
\hline & $\begin{array}{c}\text { Antibodies } \\
\text { targeting the } \\
\text { protein encoded by } \\
\text { ORF 25 }\end{array}$ & $\begin{array}{c}\text { Antibodies } \\
\text { targeting the } \\
\text { protein encoded by } \\
\text { ORF 72 }\end{array}$ & $\begin{array}{c}\text { Antibodies } \\
\text { targeting the } \\
\text { protein encoded by } \\
\text { ORF 87 }\end{array}$ \\
\hline Gills / Mantle & $0,86^{*}$ & $0,56^{* * *}$ & $0,53^{* * *}$ \\
\hline Gills / Adductor muscle & $0,67^{* *}$ & $0,86^{*}$ & $0,58^{* * *}$ \\
\hline Gills / Labial palps & $0,55^{* * *}$ & $0,59^{* * *}$ & 0,36 \\
\hline Labial palps / Adductor muscle & $0,81^{*}$ & $0,64^{* *}$ & $0,62^{* *}$ \\
\hline Labial palps / Mantle & $0,70^{* *}$ & $0,44^{* * *}$ & 0,21 \\
\hline Mantle / Adductor muscle & $0,84^{*}$ & $0,67 * *$ & $0,49^{* * *}$ \\
\hline Gills / Gonad & 0,15 & 0,20 & 0,21 \\
\hline Adductor muscle / Gonad & 0,29 & 0,24 & 0,32 \\
\hline Mantle / Gonad & 0,20 & 0,13 & 0,17 \\
\hline Labial palps / Gonad & 0,38 & 0,11 & $0,44 * * *$ \\
\hline Gills / Digestive gland & $0,53 * * *$ & 0,20 & 0,11 \\
\hline Mantle / Digestive gland & $0,43^{* * *}$ & $0,45^{* * *}$ & $0,54 * * *$ \\
\hline Labial palps / Digestive gland & 0,27 & 0,15 & 0,24 \\
\hline Adductor muscle / Digestive gland & 0,38 & 0,25 & 0,74 \\
\hline Gonad / Digestive gland & 0,08 & 0,04 & 0,06 \\
\hline
\end{tabular}

* almost perfect agreement; ** substantial agreement; *** moderate agreement accorded to the Landis and Koch numeric scale (Landis and Koch, 1977). 
Table 5. Kappa values between antibodies in respect with different organs.

\begin{tabular}{|l|c|c|c|}
\cline { 2 - 4 } \multicolumn{1}{c|}{} & $\begin{array}{c}\text { Antibodies targeting } \\
\text { proteins encoded by } \\
\text { ORF 25 and 72 }\end{array}$ & $\begin{array}{c}\text { Antibodies targeting } \\
\text { proteins encoded by } \\
\text { ORF 25 and 87 }\end{array}$ & $\begin{array}{c}\text { Antibodies targeting } \\
\text { proteins encoded by } \\
\text { ORF 72 and 87 }\end{array}$ \\
\hline Mantle & $0,62^{* *}$ & $0,41^{* * *}$ & $0,53^{* * *}$ \\
\hline Gills & $0,66^{* *}$ & $0,58^{* * *}$ & $0,56^{* * *}$ \\
\hline Digestive gland & 0,27 & 0,20 & $0,78^{* *}$ \\
\hline Gonad & $-0,03$ & 0,32 & $0,72^{* *}$ \\
\hline Adductor muscle & $0,92^{*}$ & $1,00^{*}$ & $1,00^{*}$ \\
\hline Labial palps & $0,77^{* *}$ & $0,51^{* * *}$ & $0,83^{*}$ \\
\hline
\end{tabular}

* almost perfect agreement; ** substantial agreement; *** moderate agreement accorded to the Landis and Koch numeric scale (Landis and Koch, 1977). 
Tissue distribution of ostreid herpesvirus 1 proteins in infected Pacific oyster, Crassotrea gigas

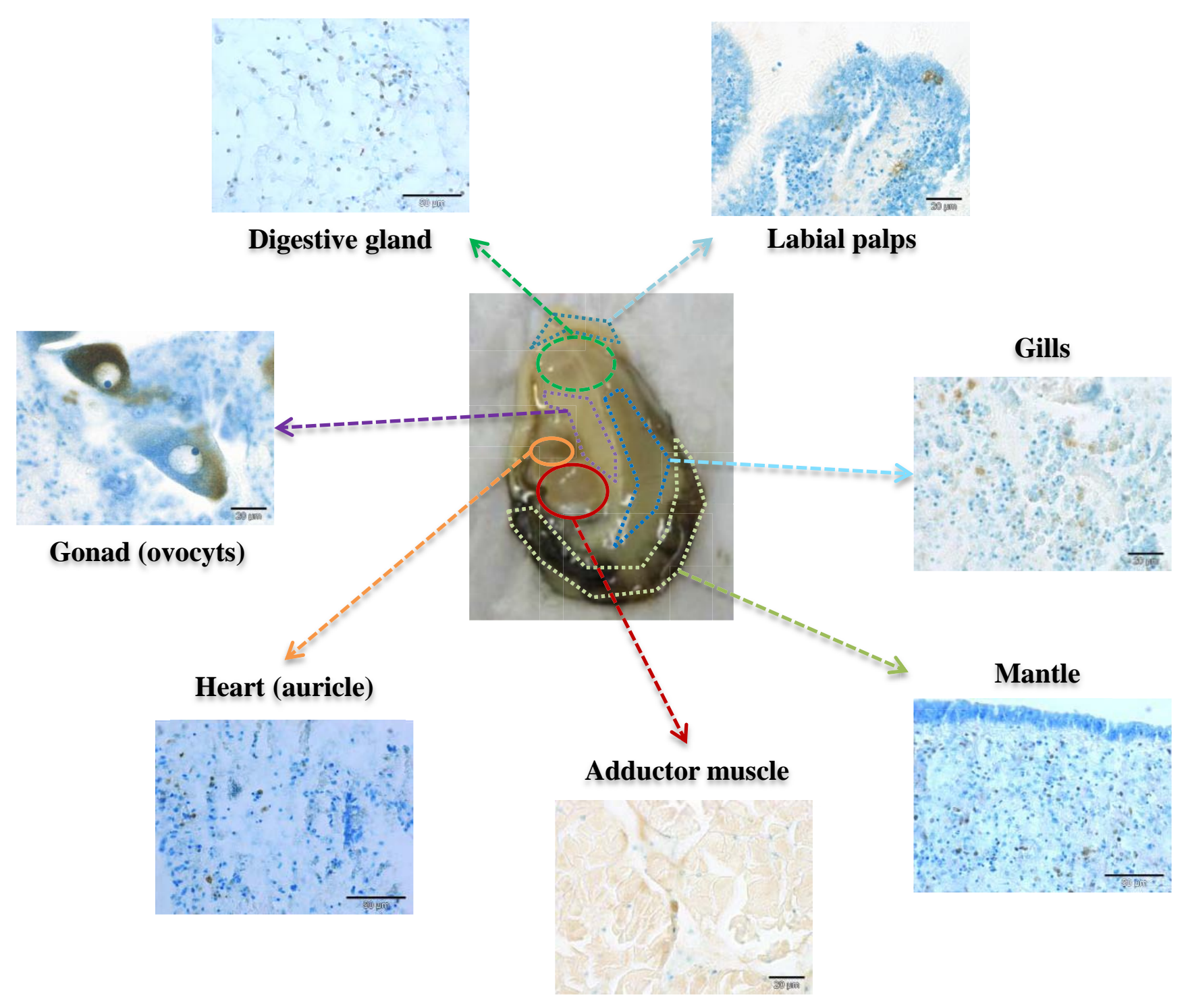

